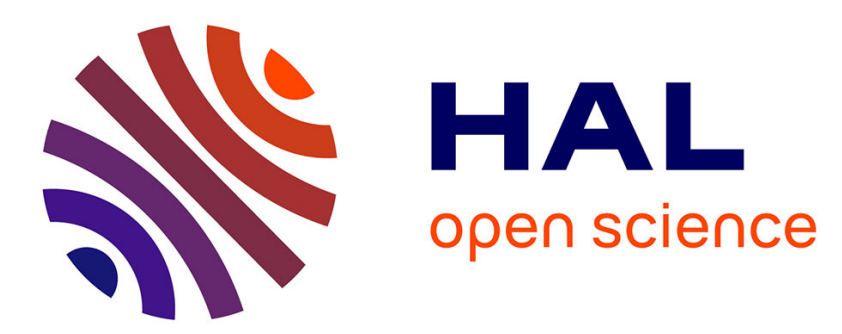

\title{
Enhanced proton transport properties of Nafion via functionalized halloysite nanotubes
}

Ibtissam Ressam, Abdelkrim El Kadib, Mohammed Lahcini, Gerrit A. Luinstra, Hubert Perrot, Ozlem Sel

\section{To cite this version:}

Ibtissam Ressam, Abdelkrim El Kadib, Mohammed Lahcini, Gerrit A. Luinstra, Hubert Perrot, et al.. Enhanced proton transport properties of Nafion via functionalized halloysite nanotubes. International Journal of Hydrogen Energy, 2018, 43 (40), pp.18578 - 18591. 10.1016/j.ijhydene.2018.05.025 hal01896484

\section{HAL Id: hal-01896484 https://hal.sorbonne-universite.fr/hal-01896484}

Submitted on 22 Oct 2018

HAL is a multi-disciplinary open access archive for the deposit and dissemination of scientific research documents, whether they are published or not. The documents may come from teaching and research institutions in France or abroad, or from public or private research centers.
L'archive ouverte pluridisciplinaire HAL, est destinée au dépôt et à la diffusion de documents scientifiques de niveau recherche, publiés ou non, émanant des établissements d'enseignement et de recherche français ou étrangers, des laboratoires publics ou privés. 


\section{Enhanced Proton Transport Properties of Nafion via Functionalized Halloysite Nanotubes}

Ibtissam Ressam ${ }^{\mathrm{a}, \mathrm{b}}$, Abdelkrim El Kadib ${ }^{\mathrm{c}}$, Mohammed Lahcini ${ }^{\mathrm{b}}$, Gerrit A. Luinstra ${ }^{\mathrm{d}}$, Hubert Perrot $^{\mathrm{a}}$, Ozlem Sel $^{\mathrm{a}}$

[a] Sorbonne Université, UPMC Univ. Paris 06, CNRS, UMR 8235, LISE, F-75005, Paris, France.

[b] Cadi Ayyad Université, Faculté des Sciences et Techniques, Laboratoire Chimie Organométallique et Macromoléculaire -Matériaux Composites - Marrakech, Morocco.

[c] Euromed Research Center, Engineering Division, Euro-Mediterranean University of Fes (UEMF) Fès-Shore, Route de Sidi Hrazem,30070 Fès, Morocco.

[d] Institut für Technische und Makromolekulare Chemie, Universität Hamburg, Bundesstr. 45, 20146 Hamburg, Germany.

Abstract: The introduction of naturally occurring fibrillary structured halloysite clays (HNTs) into the Nafion matrix resulted in an enhanced proton conductivity and a reduced activation energy for proton transport. To assess the effect of the various states of the HNTs as a membrane additive, the $\mathrm{\sigma H}^{+}$of the composite membranes (Nafion/HNTs, Nafion/HNTs$\mathrm{NH}_{2}$, Nafion/HNTs-SO $3 \mathrm{H}$ ) was measured at $30{ }^{\circ} \mathrm{C}$ and $80{ }^{\circ} \mathrm{C}$ and at different levels of relative humidity $(\% \mathrm{RH})$. An overall improvement of the $\sigma_{\mathrm{H}}{ }^{+}$of the Nafion was observed in the presence of the nanotubular additives (HNTs or HNTs-NH ) which can be attributed to the high specific surface area accommodating hydrophilic functional groups and therefore contributing to the water retention/management in the composite membrane. However, the Nafion/HNT-SO $3{ }_{3} \mathrm{H}$ composites are distinguished in terms of enhanced performance in $\mathrm{\sigma H}^{+}$ which persist in the whole range of $\% \mathrm{RH}$ levels and noted that the $\mathrm{\sigma H}^{+}$values are almost 2 times higher than native Nafion in the low humidity region $(30 \%-50 \%)$ and at $80{ }^{\circ} \mathrm{C}$. In 
agreement with the $\sigma_{\mathrm{H}}{ }^{+}$enhancement, the activation energy is lower than that of native Nafion indicating that the proton transport is facilitated in the presence of $-\mathrm{SO}_{3} \mathrm{H}$ modified HNTs, probably due to an improved connectivity and arrangement of ionic conducting domains.

Keywords: Halloysite nanotubes; Nafion; proton conduction mechanism; energy conversion; composite membranes.

\section{Introduction}

The proton exchange membrane (PEM) is the central and performance limiting part of the proton exchange membrane fuel cells (PEMFCs) [1-6]. They have also been employed as separators in many industrial applications such as chloro-alkali industry, electrodialysis and gaining tremendous interest in aqueous rechargeable or redox-flow batteries [7-9].

The membranes commonly used in PEMFCs are based on the perfluorinated polymers containing sulfonic acid groups on the side chains, such as Nafion [10-11]. However, Nafion membranes have several disadvantages such as a decrease in the proton conductivity $\left(\sigma_{\mathrm{H}}{ }^{+}\right)$at low relative humidity $(\mathrm{RH} \%)(<50 \%)$ and high temperatures $\left(>80^{\circ} \mathrm{C}\right)$, and excessive dimensional changes due to the swelling/deswelling, leading to mechanical instabilities [12]. Therefore, the chemical, mechanical and thermal properties as well as water retention behaviour of Nafion should be improved which is directly related to the optimization of the proton transport, the performance and the lifetime of the device.

In this context, the introduction of hydrophilic inorganic particles as filler to membrane matrix seems to be an appropriate strategy for maintaining $\sigma_{H^{+}}$at low humidity levels [13-14]. Over the past few decades, numerous studies have focused on the organic-inorganic hybrid materials as fuel cell membranes. These hybrid membranes are often based on a proton conducting organic polymer and an inorganic component with improved water retention 
properties. Due to the improved hydration and thermomechanical properties of these hybrid materials, an increase in the operation temperature of the PEMFCs can be expected [2].

Among the low-cost membrane components, naturally available phyllosilicates known as clays are significant due to their abundance. They have the potential to be used as efficient additives in solid electrolytes due to (i) their high water retention capacity, (ii) their nanoscale dimensions and (iii) their potential to reduce gas permeability [5]. Due to the availability of several types of clays with different structural (i.e. lamellar, tubular) and compositional characteristics [15], these materials have attracted the attention of the fuel cell community. The presence of clays in the Nafion matrix resulted in improvements in certain aspects such as thermal and mechanical properties [3] and water retention [4] of the composite membranes. As a pertinent example, Lin and Ma et al.[6] studied the effect of the Montmorillonite (MMT) on the $\sigma_{H}^{+}$and the methanol permeability of Nafion. This inorganic clay with lamellar structure was subjected to organic modification to increase its affinity to the fluorinated polymer. The oligomers bearing an organic sulfonic acid are used as intercalating agents for $\mathrm{Na}^{+}$-MMT. The resulting organo-clay with sulfonic acid functional groups were used as fillers to Nafion and contributed to the $\sigma_{H^{+}}$and also reduced its methanol permeability.

From the morphology point of view, the previous works agreed on a consensus that compared with the spherical (e.g. silica [16]) and sheet fillers (e.g. montmorillonite [6]), tubular fillers (e.g. carbon nanotubes (CNTs) [17]) display significant effects in interconnecting the ionic channels and hence forming long-range uninterrupted trajectory for proton transport. Due to the major concerns with the CNTs i.e. (i) the high electron conductivity of the nanotubes which may cause a short circuit of the device and (ii) the relatively high cost of CNTs; naturely occuring inorganic clays with tubular structure is notably preferred as membrane additives. 
Thus, in addition to lamellar clays (i.e. MMT), those with fibrous structure such as native palygorskite [18] and sepiolite [15] also served as additives to Nafion. These clays are known to be hygroscopic and their tubular morphology is considered advantageous to improve the mechanical strength of the composite membranes since they can limit the separation of Nafion chains during swelling. Nafion membranes with palygorskite fillers have shown several advantages in comparison with native Nafion, especially in terms of mechanical properties and the ability to absorb water [18]. The latter is likely to be correlated to the improvements of the $\sigma_{\mathrm{H}}^{+}$at low $\mathrm{RH} \%$ levels.

Among the fibrous structured clays, despite their great relevance, the halloysite nanotubes (HNTs) have not yet received the attention they deserve as membrane additives. HNTs have the chemical structure of $\mathrm{Al}_{2} \mathrm{Si}_{2} \mathrm{O}_{5}(\mathrm{OH})_{4} \cdot \mathrm{nH}_{2} \mathrm{O}$, where the siloxane groups are situated on the outer surface and the Al-OH groups on the inner surface of the nanotubes [19]. There are only some recent examples where HNTs are used as membrane additives and incorporated into sulfonated poly(ether ether ketone) (SPEEK) matrix. Wang et al. showed that dopaminemodified HNTs (bearing $-\mathrm{NH}_{2}$ group) increased the $\sigma_{\mathrm{H}}{ }^{+}$when dispersed into the SPEEK matrix which was attributed to the formation of ordered acid-base pairs at the SPEEK/coated HNTs interface [20]. Another method of HNT modification was also reported by the same group where this time $-\mathrm{SO}_{3} \mathrm{H}$ functionalization was done by a three-step distillationprecipitation polymerization. The modified HNTs are also used as additives to SPEEK membranes. The resulting composites showed enhanced $\sigma_{\mathrm{H}}{ }^{+}$at $25-80{ }^{\circ} \mathrm{C}$ temperature range and at $100 \% \mathrm{RH}$ level [21]. In a recent work, Liu et al. functionalized the HNTs by a first step of polydopamine coting which was followed by a process of atom transfer radical polymerization (ATRP). The authors showed that the introduction of modified HNTs into the SPEEK matrix resulted in an enhanced $\sigma_{\mathrm{H}}{ }^{+}$and a reduced activation energy for proton transport. Such enhancement was especially significant for the SPEEK/SHNT nanocomposite 
membranes at low RH \% levels. These improvements were attributed to the presence of HNTs such that; (i) an enhanced phase separation which enabled to form larger hydrophilic domains and (ii) the additional pathways for proton conduction both inside the lumens and along the outer surfaces of nanotubes were created in the composite membrane [19].

The previous studies highlighted the advantageous nature of the HNTs due to the high specific surface area, excellent mechanical and thermal stability. Additionally, they are strongly hydrophilic as a result of the surface $\mathrm{Si}-\mathrm{OH}$ and $\mathrm{Al}-\mathrm{OH}$ groups which also facilitates the functionalization of the HNTs. Also, the dispersion of HNTs in a polymer matrix is likely to be facile, since the interaction between HNTs is rather weak compared to the strong vander Waals attractions between the CNTs. In view of these characteristics and earlier [19]-[22] studies with SPEEK membranes, it is noted that the native or functionalized HNTs are definitely promising fillers to enhance the $\sigma_{H^{+}}{ }^{+}$of the PEMs. However, the obtained conductivity values of the alternative membranes composed of HNTs and SPEEK are lower than that of Nafion. Therefore, the strategy of improving the properties of Nafion benefiting from such additives can be extremely relevant, and to the best of our knowledge, such composites have not yet been reported in a systematic investigation.

Therefore, objective of the present work is to investigate the effect of the native and functionalized HNTs additives on the proton transport properties of Nafion. The functionalization steps differ from those employed in the SPEEK matrix based membranes [19]-[22]. Here, amino functions $\left(-\mathrm{NH}_{2}\right)$ were grafted by a reaction between the hydroxyl ($\mathrm{OH}$ ) functions existing on the surface of the HNTs and the ethoxysilane groups of the (3aminopropyl)triethoxysilane (APTES) [23]. Subsequently, $-\mathrm{SO}_{3} \mathrm{H}$ functional groups were grafted onto the HNTs by reacting propane sultone with the amine functions generated in the previous step. The HNTs clays were employed as additives in different forms depending on the states of functionalization: in the native state (HNTs with - $\mathrm{OH}$ functional groups), in the 
amine form $\left(\mathrm{HNTs}-\mathrm{NH}_{2}\right)$ and in the sulfonated form $\left(\mathrm{HNTs}-\mathrm{SO}_{3} \mathrm{H}\right)$. Three different distinct composite membranes (Nafion/HNTs, Nafion/HNTs-NH 2 and Nafion/HNTs-SO ${ }_{3} \mathrm{H}$ ) were evaluated in terms of $\sigma_{\mathrm{H}}{ }^{+}$at various level of $\mathrm{RH} \%$ and at temperatures of $30{ }^{\circ} \mathrm{C}$ and $80{ }^{\circ} \mathrm{C}$. The resulting composites have been investigated by various characterization techniques to unveil the enhanced structural, morphological and electrochemical properties which may lead to PEMFCs with higher performance.

\section{Materials and Methods}

2.1. Materials: Halloysite nanotubes (HNTs) used in this study was a gift from Applied Mineral Incorporation, which have the following characteristics: an inner and outer diameter between 15 and $45 \mathrm{~nm}$ and 50 and $70 \mathrm{~nm}$, respectively; and a length between 0.2 and $2 \mu \mathrm{m}$ with a cation exchange capacity (CEC) of $0.11 \mathrm{meq} / \mathrm{g}$. 3-aminopropyltriéethoxysilane (APTES) and propane sultone (PS) were used in the functionalization of the HNTs and were obtained from Sigma Aldrich. Nafion117 solution (5 wt. \% in lower aliphatic alcohols and water), nitric acid (68\%) and the solvents (dimethylacetamide (DMA), dimethylformamide (DMF), ethanol) were purchased from Sigma-Aldrich and used as received. Toluene was also purchased from Sigma-Aldrich and distilled over sodium/benzophenone prior to use.

2.2. Functionalization of HNTs: Before functionalization of the HNTs by the sulfonic acid functional groups, they were treated with 3-aminopropyltriethoxysilane (APTES) to introduce amine functions at the surface $\left(\mathrm{HNTs}-\mathrm{NH}_{2}\right)$. This step is necessary before the coupling step with propane sultone (PS). The procedure followed in our study is depicted in Scheme I and is detailed as follows:

2.2.1. Grafting amine functions via 3-aminopropyltriethoxysilane: $5 \mathrm{~g}$ of previously oven dried HNTs $\left(100{ }^{\circ} \mathrm{C}, 24 \mathrm{~h}\right)$ is mixed with $4 \mathrm{ml}$ of 3 -aminopropyltriethoxysilane (APTES) in a $120 \mathrm{ml}$ portion of anhydrous toluene which is homogenized for 30 minutes in an 
ultrasonification bath. This dispersion is refluxed at $120{ }^{\circ} \mathrm{C}$ with constant stirring for 20 hours. At the end of this treatment, the clay material is recovered by filtration and washed 6 times with anhydrous toluene. The resulting material $\left(\mathrm{HNTs}-\mathrm{NH}_{2}\right)$ is dried in an oven at 120 ${ }^{\circ} \mathrm{C}$ for 12 hours [5].

2.2.2. Sulfonic acid functionalization by ring opening of the propane sultone: $0.1 \mathrm{~g}$ of HNTs- $\mathrm{NH}_{2}$ is dispersed in $10 \mathrm{ml}$ of anhydrous toluene in a $50 \mathrm{ml}$ beaker in an ultrasonic bath for 30 minutes. Then, $106 \mathrm{mg}(0.87 \mathrm{mmol})$ propane sultone is added to this dispersion which was allowed to be stirred under nitrogen atmosphere at $70{ }^{\circ} \mathrm{C}$ for $24 \mathrm{~h}$. The suspension is

a. Modification of the Falloysite nanotubes by using (3-aninopropyl)triethoxysilane

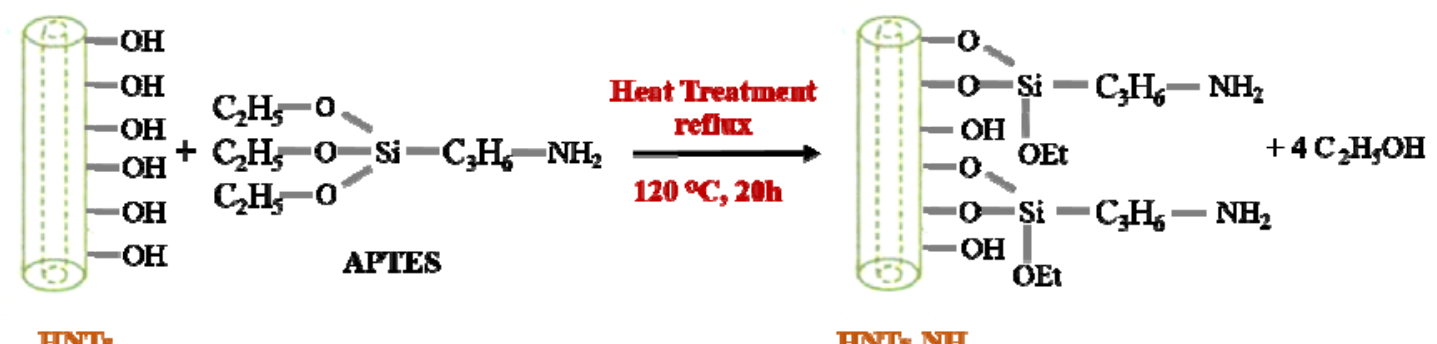

b. Modification of the amine functionalized Halloysite nanotubes by using 1,3-propane sultone

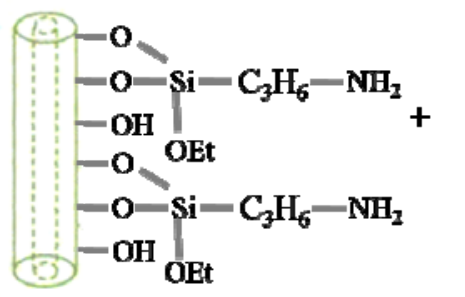

HNTs-NH

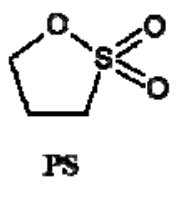

$\underset{70}{\stackrel{\circ}{\circ}, 24 \mathrm{~h}}$

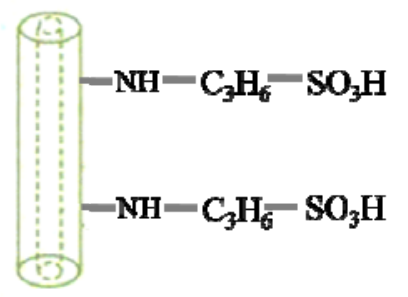

HNTs- $\mathrm{SO}_{3} \mathrm{H}$

Scheme I. Synthesis procedure of the modified halloysite nantubes (HNTs) to acquire $-\mathrm{NH}_{2}$ and $-\mathrm{SO}_{3} \mathrm{H}$ functional HNTs.

filtered and rinsed 6 times with anhydrous toluene. Finally, sulphonic acid functionalized clay $\left(\mathrm{HNTs}-\mathrm{SO}_{3} \mathrm{H}\right)$ is dried in an oven at $120{ }^{\circ} \mathrm{C}$ for $12 \mathrm{~h}$.

2.3. Elaboration of the composite membranes: Three types of membranes were prepared: Nafion/HNTs, Nafion/HNTs-NH 2 and Nafion/HNTs-SO ${ }_{3} \mathrm{H}$. In $20 \mathrm{ml}$ beakers, a $4.6 \mathrm{mg}$ 


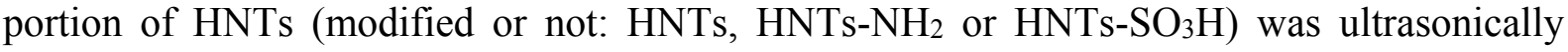
dispersed in a mixture of Nafion/DMA/DMF/ethanol with a volume ratio of 1:4:4:1 for 30 minutes. Then, the solutions were stirred at $100{ }^{\circ} \mathrm{C}$ for another $3 \mathrm{~h}$ until complete dispersion. Finally, the membranes were prepared by solution casting method in teflon molds and ovendried at $90{ }^{\circ} \mathrm{C}$ for $7 \mathrm{~h}$. The free-standing membranes were obtained after being peeled off the molds. The composite membranes are activated before the conductivity measurements by conditioning them in a solution of nitric acid $\left(\mathrm{HNO}_{3}, 1 \mathrm{M}, 50 \mathrm{ml}\right)$ for 4 hours. Then, the membranes are rinsed with bidistilled water until neutral $\mathrm{pH}$ (to remove the remaining $\left.\mathrm{HNO}_{3}\right)$.

\subsection{Structural, Morphological and Electrochemical Characterization:}

2.4.1. Structural and Morphological Characterization: The modification of the HNTs was characterized by infrared spectroscopy using an ATR-FTIR instrument (Perkin Elmer Spectrum 400 FT-IR/FT-NIR Spectrometer) in the range of $4000-400 \mathrm{~cm}^{-1}$. The morphology and the thickness of the membranes were observed using field emission gun scanning electron microscopy (FEG-SEM) (Zeiss, Supra 55). The membranes were sputtered with a thin layer of carbon prior to the analysis. High-resolution transmission electron microscopy (HRTEM) (JEOL 2010 UHR) equipped with EDX (energy dispersive x-ray) detector is also used for the morphological analysis of the HNTs. The contact angle measurements of the membranes with and without HNT additive were carried out using Krüss Easy Drop instrument at room temperature. Dry membranes were placed on the glass slides to ensure a flat surface. Deionized water was dropped onto the sample surface from a needle tip.

2.4.2. Ion-exchange-capacity determination: The ion-exchange capacity (IEC) is defined as the ratio between the number of $\mathrm{H}^{+}$ions (in mmol) and the weight of the dry membrane $\left(\mathrm{mmol} \mathrm{H} \mathrm{H}^{+}\right.$per $\mathrm{g}$ of the membrane). To determine the IEC, the membranes were soaked in $1 \mathrm{M}$ $\mathrm{NaCl}$ solution for $48 \mathrm{~h}$. The protons (released by the exchange reaction with $\mathrm{Na}^{+}$ions) were 
titrated against $0.01 \mathrm{M} \mathrm{NaOH}$ solution by using phenolphthalein as a $\mathrm{pH}$ indicator. The IEC was calculated according to the equation (1) where a and $\mathrm{N}_{\mathrm{NaOH}}$ are the volume and the normality of the $\mathrm{NaOH}$ used and $\mathrm{w}$ is the weight of the dry composite membrane.

$$
\mathrm{IEC}_{\exp }\left(\frac{\mathrm{mmol} \mathrm{H}}{\mathrm{g}}\right)=\frac{\mathrm{a} \times \mathrm{N}_{\mathrm{NaOH}}}{\mathrm{w}}
$$

2.4.3. Proton conductivity measurements: The proton conductivity of the membranes was evaluated using a laboratory-made conductivity measurement cell [24]. The membrane to be analyzed was placed on the two gold electrodes deposited on an epoxy glass printed circuit. The assembly was covered with a patterned Teflon lid which isolates the electrical contacts from the surrounding environment but exposes the defined active portion $(0.4 \mathrm{~cm} \mathrm{x} 2.5 \mathrm{~cm})$ of the membrane to the measurement media $(30-90 \%$ relative humidity $(\mathrm{RH}))$. This assembly is placed in a climatic cabinet (CLIMACELL from Fisher Bioblock Scientific) to control and maintain the temperature and relative humidity levels at constant values. The conductivity cell is connected through a BNC connector and a sealed passage on the wall of the climatic cabinet to the measuring probe of the network analyzer (Agilent 4294A). The frequency is scanned between $40 \mathrm{~Hz}$ and $100 \mathrm{MHz}$ with a $30 \mathrm{mV}$ rms sinusoidal perturbation amplitude of the signal. The resistance of the membranes was determined from the electrical impedance diagrams in the Nyquist representation. The proton conductivity $\left(\mathrm{S} \mathrm{cm}^{-1}\right)$ was calculated using the following equation (2):

$$
\sigma=\frac{\mathrm{d}}{\mathrm{R} \times \mathrm{e} \times \mathrm{L}}(2)
$$

where $e$ is the dry membrane thickness $(\mathrm{cm}), d$ is the opening between the two gold electrodes (and it is considered the active portion of the membrane $(\mathrm{cm})), L$ is the width of the membrane $(\mathrm{cm})$ and $R$ is the resistance of the membrane estimated from the electrical 
impedance measurements described below $(\Omega)$. The proton conductivity measurements were performed in the temperature range of $30-80{ }^{\circ} \mathrm{C}$ and in the range of 30-90\% $\mathrm{RH}$ levels.

2.4.4. Activation energy $\left(\mathbf{E}_{\mathbf{a}}\right)$ for proton conduction: The proton conductivity values were measured as a function of temperature at a constant value of $80 \% \mathrm{RH}$. The $E_{a}$ values are calculated from the following equation (3):

$$
\ln (\sigma)=\ln \left(\sigma_{0}\right)-\frac{\mathrm{E}_{\mathrm{a}}}{\mathrm{RT}}
$$

where $\mathrm{R}$ equals to $8.314 \mathrm{~J} . \mathrm{K}^{-1} \cdot \mathrm{mol}^{-1}$ representing the universal gas constant, $\sigma$ is the proton conductivity, $\sigma_{0}$ is the pre-exponential factor, $\mathrm{T}$ is the temperature $(\mathrm{K})$ and $\mathrm{E}_{\mathrm{a}}$ is the activation energy for proton conduction.

\section{Results and Discussion}

\subsection{The modification of the halloysite nanotubes with $-\mathrm{NH}_{2}$ and $-\mathrm{SO}_{3} \mathrm{H}$ functions}

The Nafion structure is characterized by the presence of pendant sulfonic acid functional groups on the fluorinated carbon backbone chain and they are known to participate to the proton conduction of the membranes. In analogy with Nafion, a two-step functionalization procedure is followed to endow the HNTs additives with $-\mathrm{SO}_{3} \mathrm{H}$ groups (Scheme I). This method is similar to the procedure of the grafting of silica-based materials [23]. In a first step, amino functions $\left(-\mathrm{NH}_{2}\right)$ were grafted via the condensation reaction between surface hydroxyls of HNTs and the ethoxysilane groups of the (3-aminopropyl)triethoxysilane (APTES) [23][25]. Subsequently, HNTs containing - $\mathrm{SO}_{3} \mathrm{H}$ functional groups has been prepared by the ring opening of propane sultone induced by nucleophilic addition of the amino groups generated in the previous step [26, 27] (Scheme I, step II).

The crystal structure of the native and the modified HNTs was analyzed with XRD. The diffractograms shown in Fig. SI are in good agreement with the previously published patterns [23]. The native HNTs reveal an intense peak at ca. $2 \theta=12^{\circ}$ corresponding to the basal 
spacing of $7.34 \AA$ between the two concentric tubes of HNTs which identifies the samples as

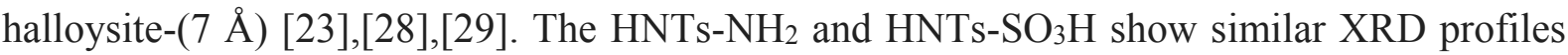
(Fig. S1), indicating that there is not a significant modification of the crystal structure. However, after chemical modification, we note a slight shift of the diffraction peak (001) (from $7.34 \AA$, at $\left(2 \theta=12^{\circ}\right)$ to $7.24 \AA,\left(2 \theta=12.20^{\circ}\right)$ which indicate a slight contraction of the basal spacing of the HNTs most likely due to the grafting of the $-\mathrm{NH}_{2}$ and $-\mathrm{SO}_{3} \mathrm{H}$ containing functional groups.

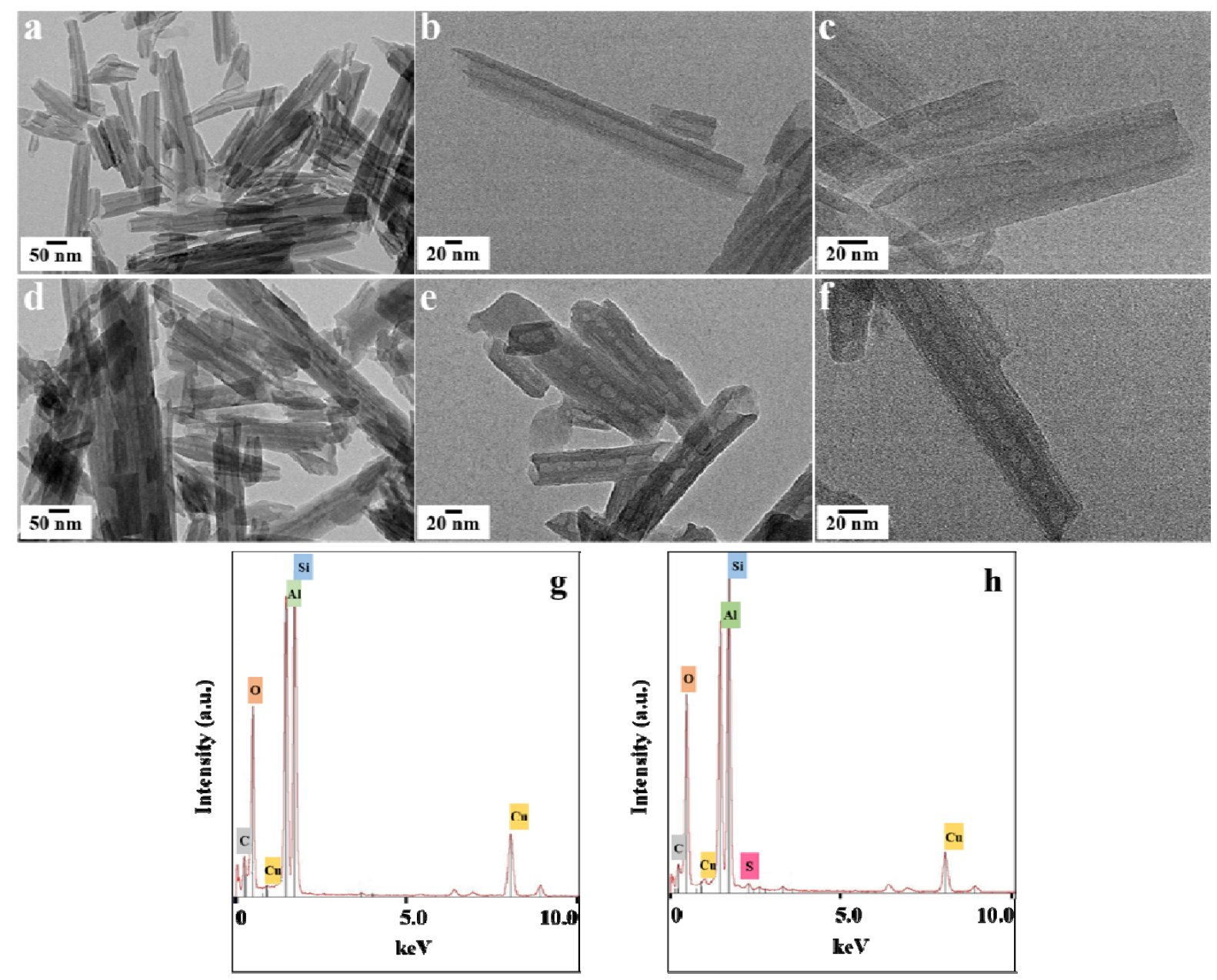

Figure 1. TEM images of HNTs $(a, b$ and $c)$ and $\mathrm{HNTs}_{-} \mathrm{SO}_{3} \mathrm{H}(\mathrm{d}$, e and $\mathrm{f})$ together with the corresponding EDX spectra of before $(\mathrm{g})$ and after $-\mathrm{SO}_{3} \mathrm{H}$ functionalization $(\mathrm{h})$. 
The effect of the functionalization steps on the morphology of the nanotubes was analyzed by electron microscopy. The SEM images of the various states (HNTs, HNTs-NH2 and HNTs$\left.\mathrm{SO}_{3} \mathrm{H}\right)$ are shown in Fig. SII which do not reveal any significant changes. Therefore, the nanostructure of the HNTs before and after the functionalization steps were observed by high resolution transmission electron microscopy (HRTEM) and the compositional changes were assessed by energy dispersive x-ray (EDX) analysis (Fig. 1). The panels a, b and c in Fig. 1 clearly reveal the well-defined tubular structure of the native HNTs with inner and outer diameters of $\sim 20 \mathrm{~nm}$ and $\sim 60 \mathrm{~nm}$, respectively. The length of the nanotubes varies between 100 and $500 \mathrm{~nm}$.

After the functionalization with (i) APTES to have $-\mathrm{NH}_{2}$ and (ii) propane sultone (PS) to have $-\mathrm{SO}_{3} \mathrm{H}$ groups (Scheme I), the tubular structure was perfectly preserved without any destruction (Fig. 1 (d-f)). Although the general morphological features remained unchanged, some kind of bridge-like structures were noticed after the two-step functionalization of the nanotubes. This modification seems to result in the apparition of the mesopores with an average diameter of $10 \mathrm{~nm}$ in the nanotubes (Fig. 1 e and $\mathbf{f}$ ) which may be considered to lead to the formation of hierarchical nanoarchitectures. Although the functionalization methodology is different, similar structures were also seen in the work of He and Lin et al [19]. These bridging points are the most likely to be formed during the first stage of functionalization of HNTs with the APTES (Scheme Ia) which are converted into sulfonic acid functional groups. Indeed, the HNTs are characterized by the presence of internal and external $-\mathrm{OH}$ functions which can react with (APTES) to form $-\mathrm{NH}_{2}$ functional microporous silica bridges. TEM images suggest that this reaction happens favorably with the internal $-\mathrm{OH}$ functions of HNTs although we cannot exclude grafting on the external surface of the nanotubes (Fig. 1 e and f). This observation is in agreement with the literature that the modification is accompanied with the consumption of the inner-surface $-\mathrm{OH}$ groups and the 
grafting takes place between these groups and hydrolyzed APTES. Furthermore, from the XRD characterizations, it is known that the inner-surface $-\mathrm{OH}$ groups in the interlayer region are not available for grafting which exclude them as grafting sites, suggesting that the vast majority of grafting occurred on the $-\mathrm{OH}$ groups at the internal surface of the lumen, which are accessible by APTES [23].

The elemental compositions were analyzed by EDX in wt and at \% for the native and modified HNTs (Fig. $1 \mathbf{g}$ and $\mathbf{h}$ ). The results are shown in Table $\mathbf{1}$ for the HNTs and HNTs-

Table 1. EDX elemental analysis (weight and atomic \%) of HNTs and $\mathrm{HNTs}^{-\mathrm{SO}_{3} \mathrm{H} .}$

\begin{tabular}{|l|c|c|c|c|}
\hline \multirow{2}{*}{ Elements } & \multicolumn{2}{|c|}{ HNTs } & \multicolumn{2}{c|}{ HNTs-SO 3 H } \\
\cline { 2 - 5 } & $\mathbf{w t} \%$ & $\mathbf{a t} \%$ & $\mathbf{w t} \%$ & at \% \\
\hline $\mathbf{S}$ & 0 & 0 & 0.47 & 0.29 \\
\hline $\mathbf{O}$ & 52 & 65.38 & 53 & 66.45 \\
\hline $\mathbf{S i}$ & 23 & 16.73 & 23 & 16.88 \\
\hline $\mathbf{A l}$ & 24 & 17.90 & 22 & 16.38 \\
\hline Ratio Si/Al & 0.95 & 0.93 & 1.04 & 1.03 \\
\hline
\end{tabular}

$\mathrm{SO}_{3} \mathrm{H}$. It should be noted that the chemical formula of the HNTs is expressed as $\mathrm{Al}_{2} \mathrm{Si}_{2} \mathrm{O}_{5}(\mathrm{OH})_{4} \cdot \mathrm{nH}_{2} \mathrm{O}$. Therefore, the elemental composition data for oxygen, silicon and aluminum cannot be directly used to evaluate the functionalization process (the presence of copper in the EDX spectra is due to the TEM grid). However, an increase of the ratio of Si to Al was observed for $\mathrm{HNTs}_{-} \mathrm{SO}_{3} \mathrm{H}(\sim 5 \%)$ which may suggest that the reaction with (3aminopropyl)triethoxysilane (Scheme Ia) is successful (Table 1) [30]. In addition, a small amount of sulfur was detected after the second step of the modification (Scheme Ia and Table 1) in $\mathrm{HNTs}-\mathrm{SO}_{3} \mathrm{H}$ spectrum which indicates the reaction between the $-\mathrm{NH}_{2}$ groups of APTES and propane sultone (PS).

The modification process of the HNTs was further analyzed with FTIR (Fig. 2). The characteristic peaks of the halloysite nanotubes are evident in the spectra. The bands at 693 $\mathrm{cm}^{-1}, 754 \mathrm{~cm}^{-1}$ and $1115 \mathrm{~cm}^{-1}$ and that at $1030 \mathrm{~cm}^{-1}$ correspond to the Si-O perpendicular 
stretching and Si-O in-plane stretching, respectively. The band at $468 \mathrm{~cm}^{-1}$ is assigned to the deformation of the Si-O-Si group present on the outer surfaces of the HNTs. The band at 910 $\mathrm{cm}^{-1}$ characteristic of the $\mathrm{O}-\mathrm{H}$ deformation of the internal Al-OH groups [31][32]. Another peak is observed around $545 \mathrm{~cm}^{-1}$ and is attributed to the Al-OH deformation present on the internal surfaces of the tubes, at the edges of the tubes and also on the surface defects on the outer surface of the tubes. The broad bands appearing at $1630 \mathrm{~cm}^{-1}$ and $3454 \mathrm{~cm}^{-1}$ are assigned to the adsorbed water. Finally, the two peaks appearing at $3621 \mathrm{~cm}^{-1}$ and $3695 \mathrm{~cm}^{-1}$
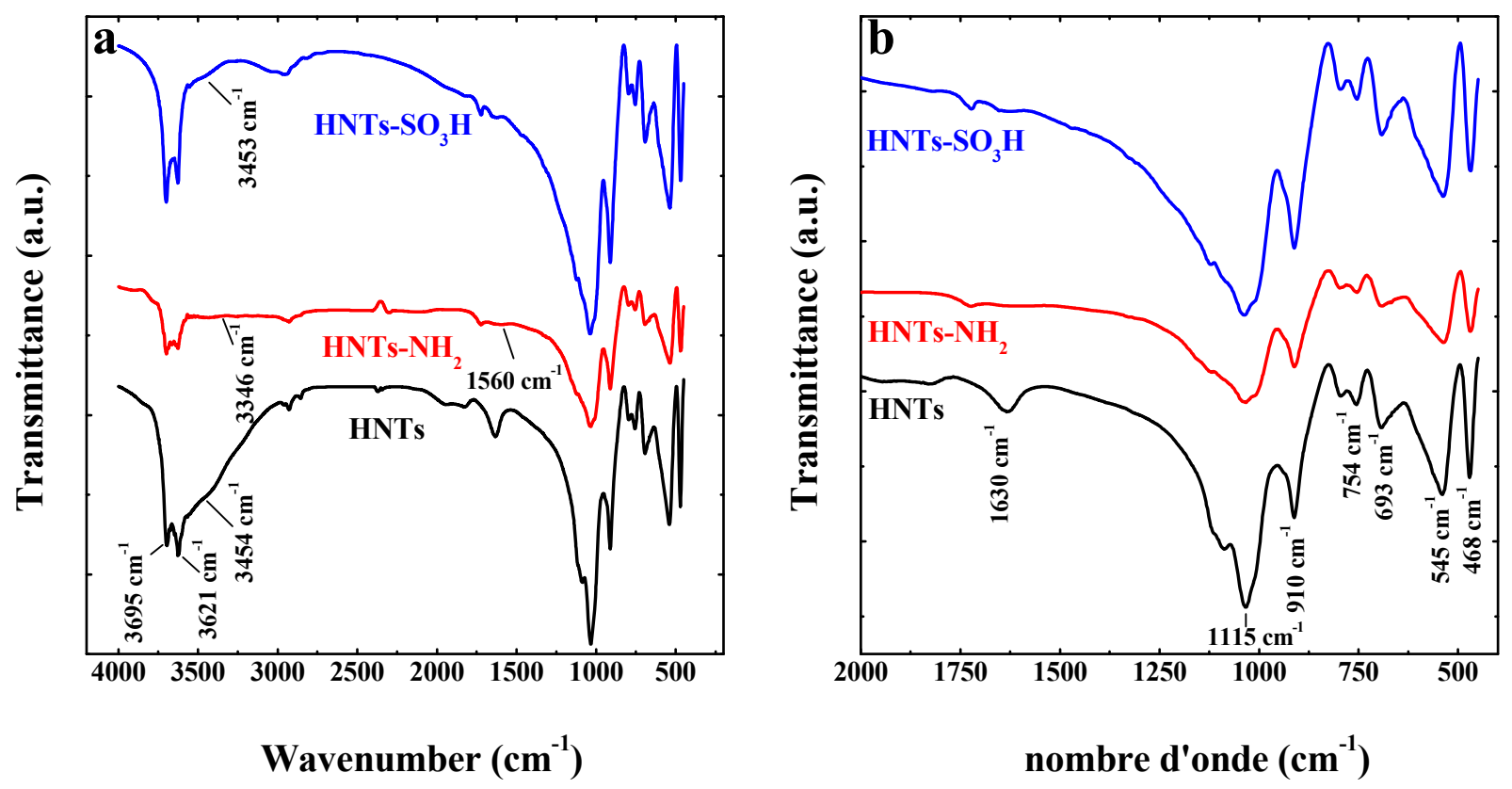

Figure 2. FTIR spectra of the HNTs before and after modification (a and b) and (b) is highlighted in yellow in the panel a.

are attributed to the $\mathrm{O}-\mathrm{H}$ stretching band of the inner -OH groups and to those of the inner surface -OH groups. It is important to note that the HNTs structures result from the wrapping of the clay layers around onto themselves to form hollow cylinders. The inner-OH groups are 
those between the tubes (interlayer region) and the inner surface $-\mathrm{OH}$ groups are on the internal surface of the lumen [23].

The bands related to the inner $\mathrm{O}-\mathrm{H}$ groups and inner surface $\mathrm{O}-\mathrm{H}$ groups of HNTs are modified after functionalization step which indicates that the APTES (Scheme Ia) has reacted with the $-\mathrm{OH}$ groups of HNTs (Fig. 2a).

One should also observe some modifications in the spectra of the $\mathrm{HNTs}_{\mathrm{NH}}$, particularly in the region related to the $-\mathrm{NH}_{2}$ groups' signatures: (i) the bands attributed to the free $-\mathrm{OH}$ groups (O-H stretching of water) located at $3454 \mathrm{~cm}^{-1}$ and at $1630 \mathrm{~cm}^{-1}$ disappeared and (ii) although relatively weak, a broad band at $3346 \mathrm{~cm}^{-1}$ appears which is attributed to the asymmetric stretching of $-\mathrm{NH}_{2}$ and another small band is visible at around $1560 \mathrm{~cm}^{-1}$ indexed

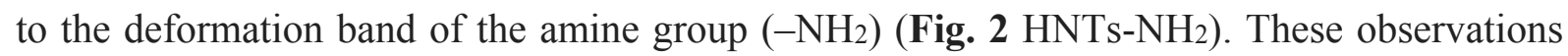
together with the modifications of the $-\mathrm{OH}$ groups of the HNTs strengthens the idea that the aminosilanization of nanotubes is successful.

Concerning the spectrum of the $\mathrm{HNTs}_{-}-\mathrm{SO}_{3} \mathrm{H}$, the characteristic peaks related to the $\mathrm{O}=\mathrm{S}=\mathrm{O}$ of $-\mathrm{SO}_{3} \mathrm{H}$ groups (at 1223, 1070, $1024 \mathrm{~cm}^{-1}$ ) are difficult to be indexed since they are mostly masked by the broad and intense peak of HNTs at $1030 \mathrm{~cm}^{-1}$ [19] (Figure 3b). This problem has also been observed in the previous works [19][22], Bai et al. [22] suggested that the increase of the IEC (ion exchange capacity) of $\mathrm{HNT}-\mathrm{SO}_{3} \mathrm{H}$ can be considered as an indication of the functionalization with sulfonic acid. The measured IEC value of $\mathrm{HNT}-\mathrm{SO}_{3} \mathrm{H}$ powder is $0.33 \mathrm{mmol} \mathrm{g}^{-1}$ which is higher than that of native HNT [21], indicating the successful functionalization. Additionally, the signatures related to the adsorbed water (i.e. the band at $3453 \mathrm{~cm}^{-1}$ ) are slightly more pronounced in the HNTs-SO 3 H spectra compared with that of HNTs- $\mathrm{NH}_{2}$, which may be beneficial for the proton conductivity and will be evaluated in section 3.3. 


\subsection{The structural and morphological characterization the Nafion/Halloysite nanotubes composite membranes}

The modified clays exhibited desirable chemical attributes such as $-\mathrm{SO}_{3} \mathrm{H}$ groups, which are beneficial for proton conductivity and additional $-\mathrm{OH}$ (unreacted $-\mathrm{OH}$ groups of HNTs) and $\mathrm{NH}_{2}$ groups for enhanced water adsorption which may contribute to balance the hydrophobicity and hydrophilicity of the membranes. The composite membranes were prepared by solution casting method and free-standing membranes were obtained after peeling them off the substrates. The resulting membranes were flexible and showed good mechanical strength (for $<7$ wt \% HNTs in Nafion). The optimal loading of additives depends on their size and shape, which has direct effect in the final nanostructuration of the membrane, [33] e.g. 3-5 wt \% was reported for modified montmorillonite/Nafion composites [34]. In our case, the membranes with 5 wt $\%$ additive leads to good apparent mechanical properties (membranes exceeding $7 \mathrm{wt} \%$ additive are brittle) and are subjected to a profound analysis thereafter. Specifically, the composite membranes with HNTs and Nafion were processed and acid-group functionalized $\left(-\mathrm{SO}_{3} \mathrm{H}\right)$, base-group functionalized $\left(-\mathrm{NH}_{2}\right)$ and neutral $(-\mathrm{OH})$ states of the HNTs were evaluated.

Figure 3a shows a digital photo of the Nafion/HNTs- $\mathrm{SO}_{3} \mathrm{H}$ composite membrane. The membrane is transparent, homogeneous and flexible, and they can be prepared in different dimensions and thickness (here is about $10 \mu \mathrm{m}$ and tailorable). In order to visualize the nanotubes in the composite, the membranes were cut and the cross-section of the membranes was analyzed by FEG-SEM which reveals that the $\mathrm{HNTs}-\mathrm{SO}_{3} \mathrm{H}$ conserves an intact tubular 

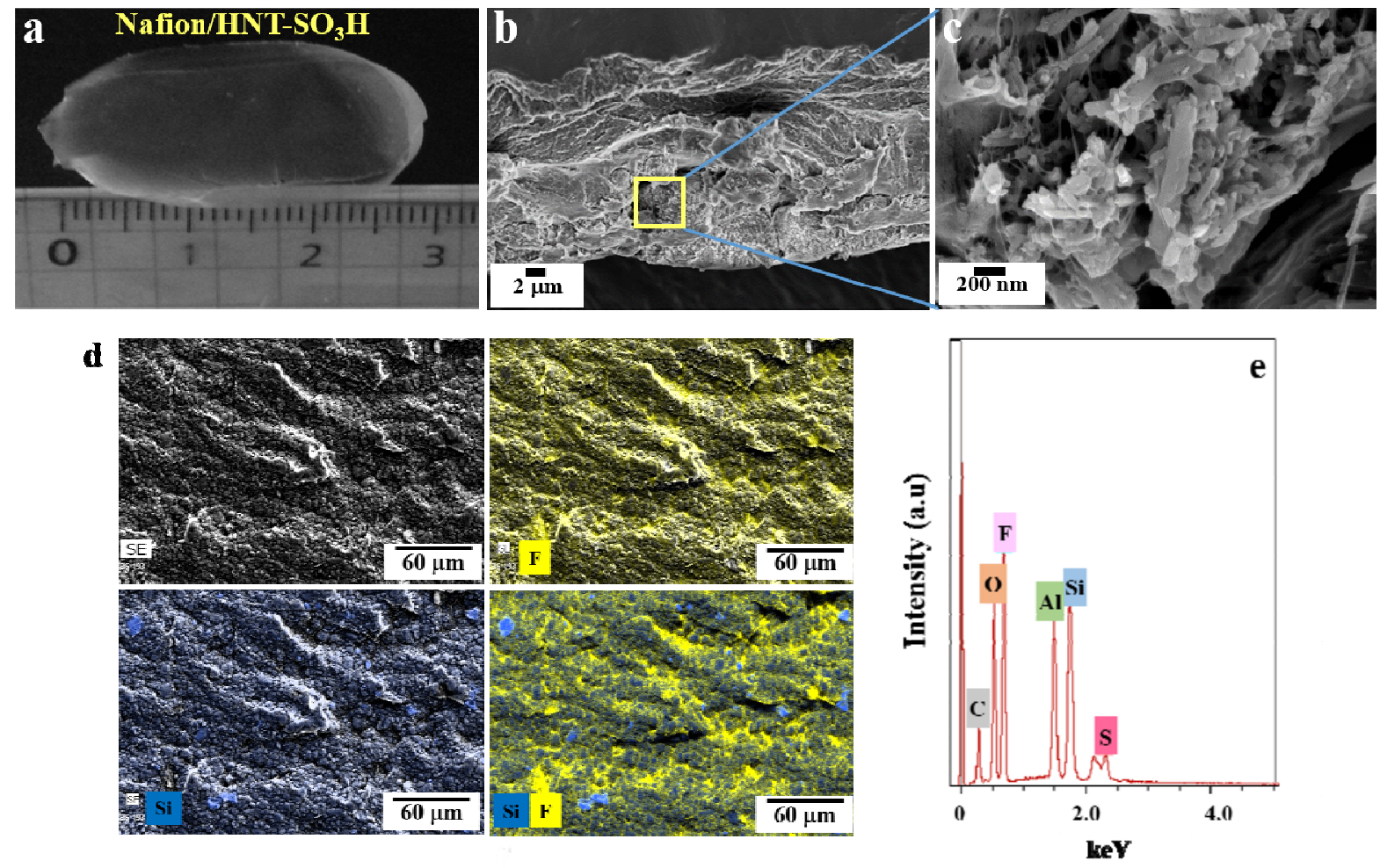

Figure 3. A digital photo (a), FEG-SEM images of the cross-section (b and c), EDX mappings (d) and the EDX spectra (e) of the Nafion/HNT-SO ${ }_{3} \mathrm{H}$ composite membranes.

structure (Figure 3b and 3c). They are relatively well dispersed within the Nafion matrix, without too much agglomeration of the nanotubes. The presence of $-\mathrm{SO}_{3} \mathrm{H}$ groups is likely to contribute to this good dispersion which is expected to preserve and further improve the continuity of the protonic pathways inside the Nafion matrix. It is important to note that there is no significant difference in terms of homogeneity of the composite membranes in the presence of native $\mathrm{HNT}$ and the $\mathrm{HNT}-\mathrm{SO}_{3} \mathrm{H}$. This is probably due to the strong interactions between the silanol groups of HNT (protonated in the acidic media) and the sulfonate groups of the Nafion [35]. The Nafion/HNT-SO ${ }_{3} \mathrm{H}$ composite membranes probably also benefit from these interactions. 
Furthermore, the interactions between the HNTs nanotubes are relatively weak, for example compared to the strong van der Walls interactions between the carbon nanotubes, therefore, the HNTs can be much more easily dispersed [19].

The FEG-SEM analyzes coupled with an EDX detector allow us to determine, at the micrometric scale the distribution of the various chemical elements of the $\mathrm{HNTs}_{-} \mathrm{SO}_{3} \mathrm{H}$ clay within the Nafion polymer matrix (Fig. 3d). Indeed, a homogeneous and uniform distribution of the chemical elements characterizing the $\mathrm{HNTs}-\mathrm{SO}_{3} \mathrm{H}$ such as silicium and aluminum as well as the main elements of the Nafion such as the fluorine were observed (only Si and F maps are shown in Fig. 3d). The EDX maps also point out the presence of granular domains rich in silicon and in aluminum (Fig. 3d), but overall, the distribution of the domains containing both the fluorine and silicium is fairly homogeneous, further indicating that the HNTs- $\mathrm{SO}_{3} \mathrm{H}$ is well dispersed within the Nafion. Although it is difficult to distinguish between the sulfur from Nafion and from the $\mathrm{HNT}$ functionalized with $-\mathrm{SO}_{3} \mathrm{H}$, the presence of fluorine, silicium and aluminum all together in the Nafion/HNTs-SO ${ }_{3} \mathrm{H}$ membranes (Fig. 3e) indicates the formation of a composite membrane (the EDX spectra of the HNTs and HNTs-SO ${ }_{3} \mathrm{H}$ powders alone shown in Fig. 1 g and $\mathbf{1 h}$ ).

Additionally, FTIR spectra of the composite membranes were compared with those of the native Nafion membrane and the $\mathrm{HNTs}_{-} \mathrm{SO}_{3} \mathrm{H}$ powder (Fig. 4). Regarding the spectrum of the Nafion, the absorption bands appearing at 1142 and $1208 \mathrm{~cm}^{-1}$ correspond to the symmetrical and asymmetrical vibrations of the $-\mathrm{CF}_{2}$ groups present in the hydrophobic fluorocarbon skeleton. The band located at $1059 \mathrm{~cm}^{-1}$ is assigned to the symmetric stretching band of the 


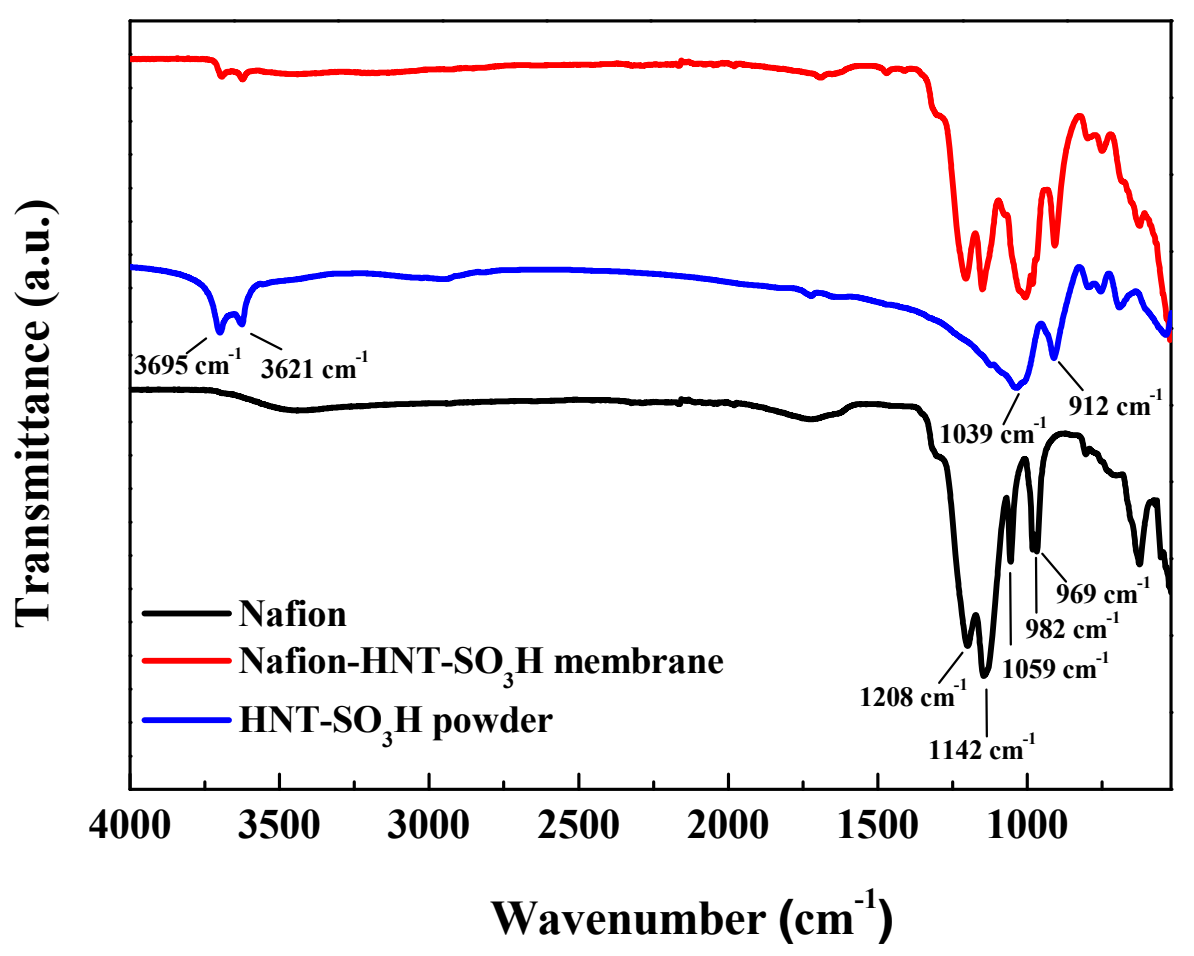

Figure 4. FTIR spectra of the composite membrane (Nafion/HNTs- $\left.\mathrm{SO}_{3} \mathrm{H}\right)$ in comparison with the native Nafion membrane and the $\mathrm{HNTs}-\mathrm{SO}_{3} \mathrm{H}$ powder.

-SO ${ }_{3} \mathrm{H}$ group. The peaks at 969 and $982 \mathrm{~cm}^{-1}$ are attributed to the presence of two ether bonds (-C-O-C-) in the Nafion side chain [36]. The spectrum of the $\mathrm{HNTs}_{-} \mathrm{SO}_{3} \mathrm{H}$ powder shows the characteristic peaks corresponding to halloysite structure $\left(1039 \mathrm{~cm}^{-1}\right.$ and $912 \mathrm{~cm}^{-1}$ related to the $\mathrm{Si}-\mathrm{O}-\mathrm{Si}$ and $-\mathrm{Al}-\mathrm{O}$ stretching and deformation, respectively) which are clearly present in the composite membranes (Fig. 4). Therefore, the spectrum of the composite membrane showing the signatures of the both Nafion and $\mathrm{HNTs}_{-} \mathrm{SO}_{3} \mathrm{H}$ components indicates the successful integration of the modified HNTs into the Nafion matrix.

Since the ion conducting membranes are used in environments where water exists as a both a liquid and vapor, it is important to understand how liquid water interacts with the membrane surfaces [37]. Membrane wettability tests were done by contact angle measurements at RT using water as solvent medium. In order to control the water content, all the membranes were kept under the same conditions before the measurements. 
The Fig. 5 compares the spreading ability of the water droplet on the membrane surfaces of the native Nafion, Nafion/HNTs, Nafion/HNTs-NH2 and
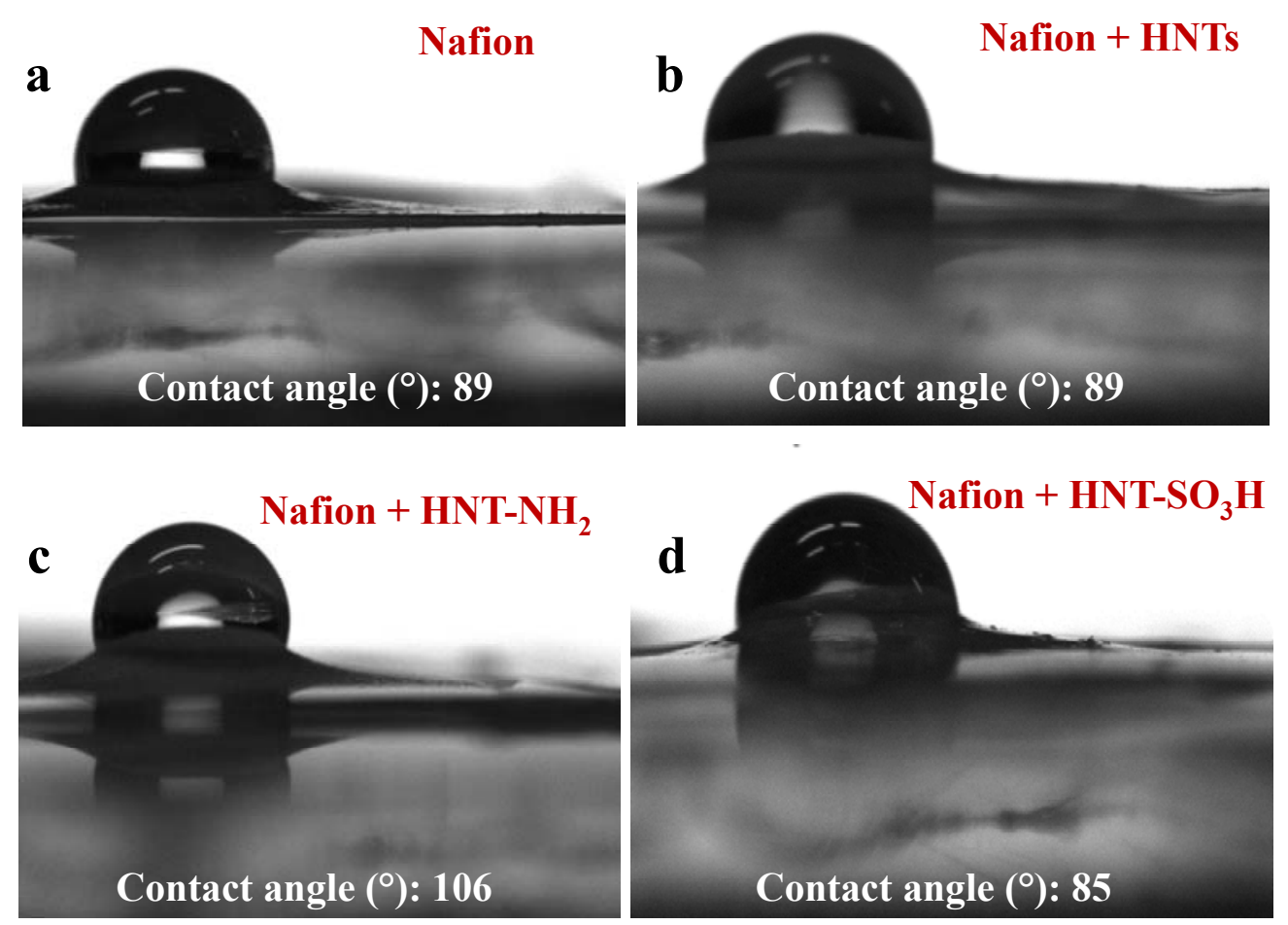

Figure 5. Comparison of membrane contact angles of Nafion (a), with native HNTs (b), with HNTs-NH2 (c) and with HNTs-SO $3 \mathrm{H}(\mathrm{d})$.

Nafion/HNTs-SO $\mathrm{SO}_{3} \mathrm{H}$. Fig. 5a shows that the contact angle value of the native Nafion membrane is $89^{\circ} \pm 5^{\circ}$ which is in good agreement with literature reports [38]. The contact angle of the composite membranes with HNTs (Nafion/HNTs) (Fig. 5b) remained unchanged whereas that of Nafion/HNTs-NH 2 was increased significantly reaching $106^{\circ} \pm 5^{\circ}$ (Fig. 5c). Further sulfonic acid functionalization of the additives leaded to a decrease in the contact angle, which means that the addition of $\mathrm{HNTs}_{-} \mathrm{SO}_{3} \mathrm{H}$ within the Nafion matrix increases the hydrophilicity of the membrane (Fig. 5d). This property is likely to have a positive effect on 
the hydrophilic/hydrophobic balance and the water retention ability of the composite membrane that may be beneficial for an optimized proton conductivity of the membrane.

\subsection{Proton conduction properties of the Nafion/Halloysite nanotubes composite}

\section{membranes}

Proton conductivity $\left(\sigma_{\mathrm{H}}^{+}\right)$is one of the main parameters evaluating the performance of proton exchange membranes. To assess the effect of the various states of the HNTs as a membrane additive, the $\sigma_{\mathrm{H}}{ }^{+}$of the composite membranes (Nafion/HNTs, Nafion/HNTs-NH2, Nafion/HNTs-SO ${ }_{3} \mathrm{H}$ ) were measured at $30{ }^{\circ} \mathrm{C}$ and $80{ }^{\circ} \mathrm{C}$ and at different levels of relative humidity (Fig. 6). The $\sigma_{\mathrm{H}}{ }^{+}$of the native Nafion membrane was also measured with the same set-up as a reference. A comparative study was performed, variation of the $\sigma_{H}{ }^{+}(\%)$ in the absence and the presence of the additives is discussed.

The data presented in Fig. 6 indicate an overall improvement of the $\sigma_{\mathrm{H}}{ }^{+}$of the Nafion in the presence of the additives. The incorporation of the native or modified HNTs in the Nafion must have a facilitating effect on the transport of protons thus leading to a higher $\sigma_{H}{ }^{+}$than that of native Nafion both at $30{ }^{\circ} \mathrm{C}$ and $80{ }^{\circ} \mathrm{C}$ and for $\% \mathrm{RH}$ values in the range of $30-90 \% \mathrm{RH}$. The improvements in the transport properties of the proton in the presence of HNTs (functionalized or not) can be attributed to the morphology of the additives, i.e. nanotubular structure providing high specific surface area and the physical characteristics such as hydrophilic functional groups contributing to the water retention/management in the composite membrane (Scheme I). It is important to note that the presence of the Si-OH and Al-OH groups endows native HNTs with strong hydrophilicity.

Among the three different types of HNTs additives, the sulfonic acid functionalized form $\left(\mathrm{HNTs}_{-} \mathrm{SO}_{3} \mathrm{H}\right)$ resulted in the highest $\sigma_{\mathrm{H}^{+}}$(Fig. 6). For example, a $\sigma_{\mathrm{H}^{+}}$value of $73 \mathrm{mS} . \mathrm{cm}^{-1}$ 
was reached at $80{ }^{\circ} \mathrm{C}$ at $90 \% \mathrm{RH}$ for the composite membrane, whereas it is $49 \mathrm{mS} . \mathrm{cm}^{-1}$ for the native Nafion, which presents an increase of $46 \%$ of the $\mathrm{\sigma H}^{+}$in the presence of the HNTs$\mathrm{SO}_{3} \mathrm{H}$ additive.

The beneficial aspects of the HNTs in terms of morphology and the presence of additional $\mathrm{SO}_{3} \mathrm{H}$ groups after the functionalization steps (Scheme I) must concomitantly lead to the

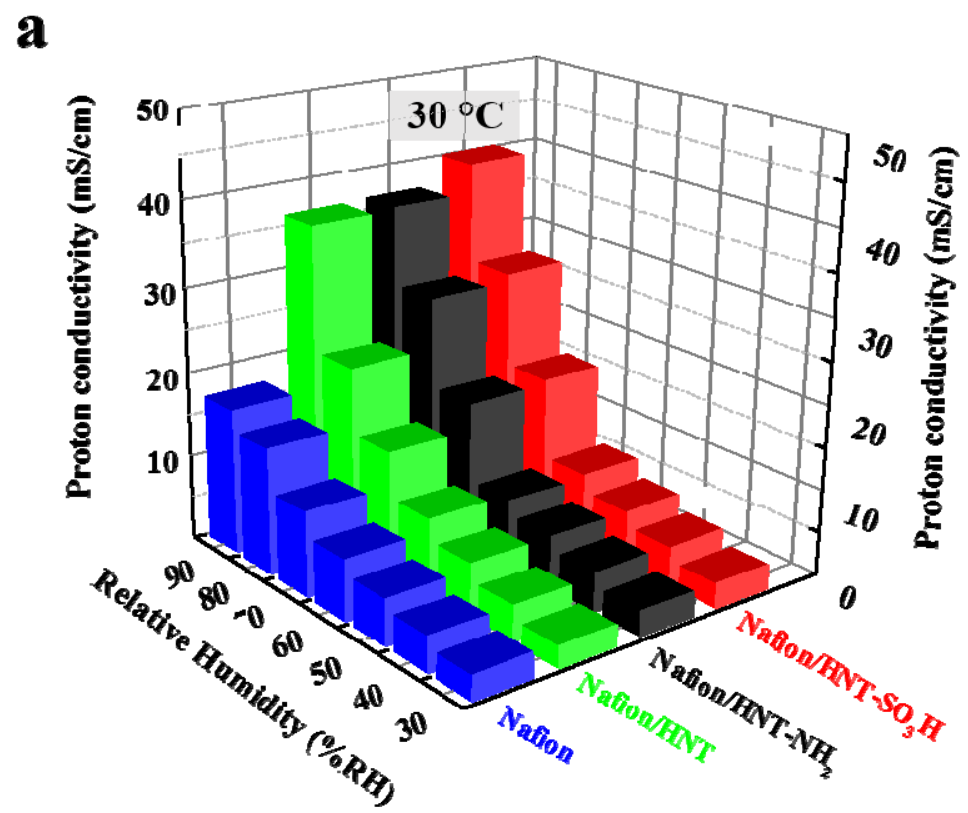

b

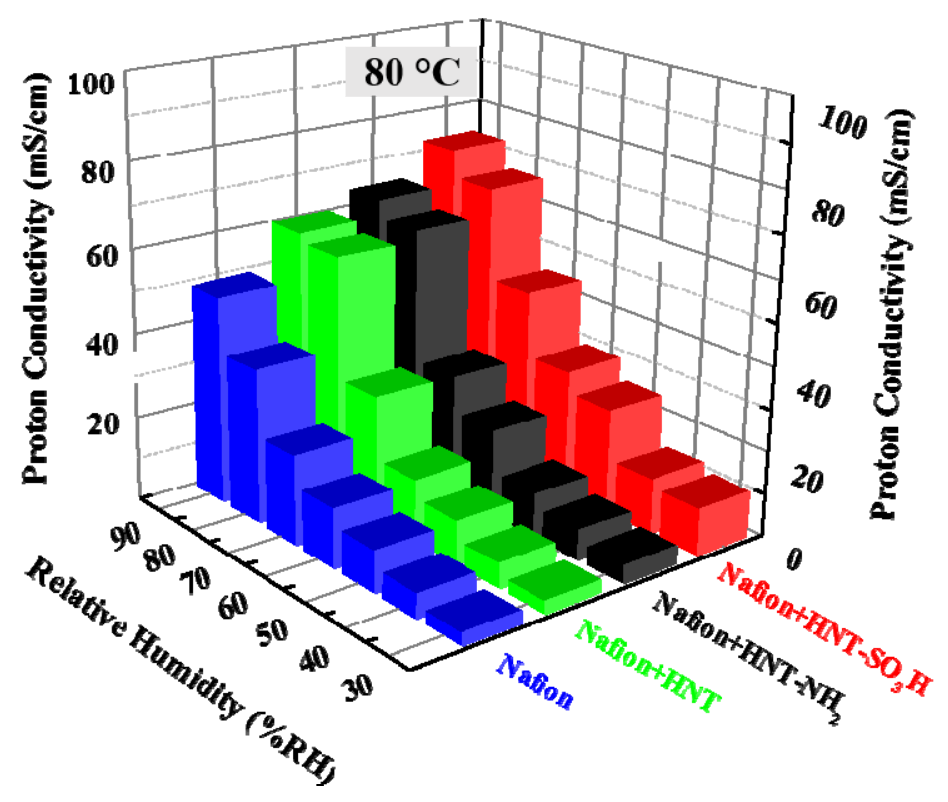


Figure 6. Comparison of the proton conductivity of the Nafion/HNTs, Nafion/HNTs- $\mathrm{NH}_{2}$, Nafion/HNTs-SO $3 \mathrm{H}$ composite membranes with the native Nafion membrane at $30{ }^{\circ} \mathrm{C}$ (a) and $80{ }^{\circ} \mathrm{C}(\mathrm{b})$ and at different humidity levels $(30 \%-90 \% \mathrm{RH})$.

improvements in the proton transport. Additionally, the "bridge like structures" created within the nanotubes during the functionalization steps (Fig. 2e and 2f) must provide a higher specific surface area for the functionalization with the $-\mathrm{SO}_{3} \mathrm{H}$ groups and offer a better percolated functionalized network which is beneficial for proton conduction. It is difficult to predict the exact location of the $-\mathrm{SO}_{3} \mathrm{H}$ groups of the $\mathrm{HNTs}-\mathrm{SO}_{3} \mathrm{H}$, they can be on the surface, inside the nanotubes or on the surface of these "bridge-like structures" (Fig. 2e and 2f). The FTIR spectra (Fig. 2) indicates that the functionalization of the HNTs with APTES mostly occurs with the inner $-\mathrm{OH}$ groups but not with the inner surface $-\mathrm{OH}$ groups. Thus, further functionalization with propane sultone in a subsequent step should also take place inside the nanotubes leading to the $-\mathrm{SO}_{3} \mathrm{H}$ functional groups inside the nanotubes and on the surface of the "bridge-like structures" (Fig. 2e and 2f) which are created after the reaction with the APTES. Once the HNTs-SO${ }_{3} \mathrm{H}$ additive is dispersed in the Nafion matrix, it will probably be placed at the interface close to the hydrophilic region of the latter. A reinforced proton conducting network with additional $-\mathrm{SO}_{3} \mathrm{H}$ groups should then assure a continuous pathway and result in low values of resistance for proton conduction.

Moreover, it is noted that the presence of $\mathrm{HNTs}_{-} \mathrm{SO}_{3} \mathrm{H}$ enhances the $\sigma_{\mathrm{H}}{ }^{+}$at low levels of relative humidity (as low as $30 \% \mathrm{RH}$ ). This latter effect is more significant at $80^{\circ} \mathrm{C}$ which probably strengthens the idea that the hydrophilic inorganic additive also contributes to the water retention in the composite membrane.

To better position and compare the improvements that are offered by the HNTs based additives, a selection of the composite membranes available in the literature is given in Table 
II. Inorganic clays such as Montmorillonite (MMT) and Laponite (Lp), either in native form or functionalized with $-\mathrm{SO}_{3} \mathrm{H}$ groups have been used as additives to Nafion [6],[16],[39],[40].

Although some benefits were observed in terms of reduced permeability to methanol and hydrogen, the addition of MMT clays to Nafion mostly resulted in a decrease of the $\sigma_{H^{+}}{ }^{+}[6]$. Regarding the Laponite/Nafion composites, certain improvements in the $\sigma_{\mathrm{H}}{ }^{+}$have been observed but the beneficial contribution to $\sigma_{\mathrm{H}}{ }^{+}$is lost beyond a further decrease in relative humidity (lower than 70\% RH) [40]. When additives such as graphene oxides (GO) are used in Nafion, for example with 6 wt \% w.r.t Nafion, at $100 \%$ RH, $62 \%$ and $66 \%$ of increase in

Table II. Comparison of selected composite membrane performances.

\begin{tabular}{|c|c|c|c|c|}
\hline Membrane Type & $\sigma_{H_{+}}\left(S \mathrm{~cm}^{-1}\right)$ & $\begin{array}{c}\text { Comment on the composite } \\
\text { performance }\end{array}$ & $\begin{array}{l}\text { Low \%RH } \\
\text { data }\end{array}$ & Ref. \\
\hline Nafion recast & $49 \times 10^{-3}, 80^{\circ} \mathrm{C}, 90 \% \mathrm{RH}$ & \multirow[t]{2}{*}{$46 \% \sigma_{\mathrm{H}}{ }^{+}$increase w.r.t. Nafion } & \multirow[t]{4}{*}{ yes } & \multirow[t]{4}{*}{ This work } \\
\hline Nafion/HNTs-SO 3 H & $73 \times 10^{-3}, 80^{\circ} \mathrm{C}, 90 \% \mathrm{RH}$ & & & \\
\hline Nafion recast & $3 \times 10^{-3}, 80^{\circ} \mathrm{C}, 30 \% \mathrm{RH}$ & \multirow[t]{2}{*}{$250 \% \mathrm{\sigma H}^{+}$increase w.r.t. Nafion } & & \\
\hline Nafion/HNTs-SO ${ }_{3} \mathrm{H}$ & $11 \times 10^{-3}, 80^{\circ} \mathrm{C}, 30 \% \mathrm{RH}$ & & & \\
\hline Nafion212 & $13.5 \times 10^{-3}, 18^{\circ} \mathrm{C}, 33 \% \mathrm{RH}$ & \multirow{2}{*}{$\begin{array}{l}87 \% \sigma_{\mathrm{H}^{+}} \text {decrease w.r.t to } \\
\text { Nafion } 212 \text {, No data at } 80{ }^{\circ} \mathrm{C} \\
\end{array}$} & \multirow{2}{*}{ yes } & \multirow[t]{2}{*}{39} \\
\hline Nafion/5wt\% MMT $^{a}$ & $1.7 \times 10^{-3}, 18^{\circ} \mathrm{C}, 33 \% \mathrm{RH}$ & & & \\
\hline Nafion & $80 \times 10^{-3}, 25^{\circ} \mathrm{C}, 100 \% \mathrm{RH}$ & \multirow{3}{*}{$\begin{array}{l}31 \% \sigma_{\mathrm{H}}^{+} \text {increase w.r.t to } \\
\text { Nafion with TEOS:SIT; } 25 \% \\
\sigma_{\mathrm{H}}^{+} \text {decrease w.r.t to Nafion } \\
\text { with MMT. No data at } 80{ }^{\circ} \mathrm{C}\end{array}$} & \multirow[t]{3}{*}{ no } & \multirow[t]{3}{*}{16} \\
\hline Nafion/5wt\% MMT $^{a}$ & $60 \times 10^{-3}, 25^{\circ} \mathrm{C}, 100 \% \mathrm{RH}$ & & & \\
\hline Nafion/TEOS:SIT ${ }^{\mathbf{b}}$ & $105 \times 10^{-3}, 25^{\circ} \mathrm{C}, 100 \% \mathrm{RH}$ & & & \\
\hline Nafion & $95 \times 10^{-3}, 25^{\circ} \mathrm{C}, 100 \% \mathrm{RH}$ & \multirow{2}{*}{$\begin{array}{l}21 \% \sigma_{\mathrm{H}^{+}} \text {increase w.r.t to } \\
\text { Nafion; No data at } 80{ }^{\circ} \mathrm{C}\end{array}$} & \multirow{2}{*}{ no } & \multirow{2}{*}{6} \\
\hline Nafion/5wt\% -MMT-Sc & $115 \times 10^{-3}, 25^{\circ} \mathrm{C}, 100 \% \mathrm{RH}$ & & & \\
\hline Nafion & $21 \times 10^{-3}, 25^{\circ} \mathrm{C}, 98 \% \mathrm{RH}$ & \multirow{3}{*}{$\begin{array}{l}38 \% \sigma_{\mathrm{H}}{ }^{+} \text {increase w.r.t to } \\
\text { Nafion with Lp-g }\end{array}$} & \multirow[t]{5}{*}{ yes } & \multirow[t]{5}{*}{40} \\
\hline Nafion/10wt\%-Lp ${ }^{d}$ & $23 \times 10^{-3}, 25^{\circ} \mathrm{C}, 98 \% \mathrm{RH}$ & & & \\
\hline Nafion/10wt\%-Lp-g ${ }^{\mathrm{e}}$ & $29 \times 10^{-3}, 25^{\circ} \mathrm{C}, 98 \% \mathrm{RH}$ & & & \\
\hline Nafion & $2 \times 10^{-3}, 25^{\circ} \mathrm{C}, 70 \% \mathrm{RH}$ & \multirow{2}{*}{$\begin{array}{l}50 \% \sigma_{\mathrm{H}}^{+} \text {increase w.r.t to } \\
\text { Nafion with Lp-g }\end{array}$} & & \\
\hline Nafion/10wt\%-Lp-g ${ }^{\mathrm{e}}$ & $4 \times 10^{-3}, 25^{\circ} \mathrm{C}, 70 \% \mathrm{RH}$ & & & \\
\hline Nafion recast & $40 \times 10^{-3}, 30^{\circ} \mathrm{C}, 100 \% \mathrm{RH}$ & \multirow{2}{*}{$\begin{array}{l}62 \% \sigma_{\mathrm{H}}^{+} \text {increase w.r.t to } \\
\text { Nafion }\end{array}$} & \multirow[t]{4}{*}{ no } & \multirow[t]{4}{*}{41} \\
\hline Nafion/GO $\mathbf{G O}^{\mathrm{f}}$ & $65 \times 10^{-3}, 30^{\circ} \mathrm{C}, 100 \% \mathrm{RH}$ & & & \\
\hline Nafion recast & $90 \times 10^{-3}, 80^{\circ} \mathrm{C}, 100 \% \mathrm{RH}$ & \multirow{2}{*}{$\begin{array}{l}66 \% \sigma^{+} \text {increase w.r.t to } \\
\text { Nafion }\end{array}$} & & \\
\hline Nafion/GO ${ }^{\mathbf{f}}$ & $150 \times 10^{-3}, 80^{\circ} \mathrm{C}, 100 \% \mathrm{RH}$ & & & \\
\hline Nafion & $\begin{array}{l}130 \times 10^{-3}, 80^{\circ} \mathrm{C}, 100 \% \mathrm{RH} \\
0.025 \times 10^{-3}, 80^{\circ} \mathrm{C}, 0 \% \mathrm{RH}\end{array}$ & \multirow{2}{*}{$\begin{array}{l}73 \% \mathrm{\sigma H}^{+} \text {increase at } 80^{\circ} \mathrm{C}, 100 \\
\% \mathrm{RH} \text { and } 140 \% \mathrm{\sigma H}^{+} \text {increase at } \\
80^{\circ} \mathrm{C}, 0 \% \mathrm{RH} \text { w.r.t to Nafion }\end{array}$} & \multirow[t]{2}{*}{ yes } & \multirow[t]{2}{*}{42} \\
\hline Nafion/10 wt\% MXene & $\begin{array}{l}225 \times 10^{-3}, 80^{\circ} \mathrm{C}, 100 \% \mathrm{RH} \\
0.060 \times 10-3,80^{\circ} \mathrm{C}, 0 \% \mathrm{RH}\end{array}$ & & & \\
\hline Chitosan (CS) & $11 \times 10^{-3}, 25^{\circ} \mathrm{C}, 100 \% \mathrm{RH}$ & \multirow{3}{*}{ 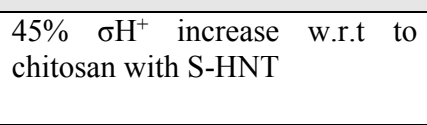 } & \multirow[t]{6}{*}{ no } & \multirow[t]{6}{*}{22} \\
\hline CS/HNTs & $10 \times 10^{-3}, 25^{\circ} \mathrm{C}, 100 \% \mathrm{RH}$ & & & \\
\hline CS/S-HNTs & $16 \times 10^{-3}, 25^{\circ} \mathrm{C}, 100 \% \mathrm{RH}$ & & & \\
\hline Chitosan (CS) & $24 \times 10^{-3}, 80^{\circ} \mathrm{C}, 100 \% \mathrm{RH}$ & \multirow{3}{*}{$\begin{array}{l}75 \% \sigma \mathrm{H}^{+} \text {increase w.r.t to } \\
\text { chitosan with S-HNT }\end{array}$} & & \\
\hline CS/HNTs & $15 \times 10^{-3}, 80^{\circ} \mathrm{C}, 100 \% \mathrm{RH}$ & & & \\
\hline CS/S-HNTs & $42 \times 10^{-3}, 80^{\circ} \mathrm{C}, 100 \% \mathrm{RH}$ & & & \\
\hline
\end{tabular}




\begin{tabular}{|c|c|c|c|c|}
\hline SPEEK $^{g}$ & $15 \times 10^{-3}, 25^{\circ} \mathrm{C}, 100 \% \mathrm{RH}$ & \multirow{3}{*}{$\begin{array}{l}26 \% \sigma_{\mathrm{H}}^{+} \text {increase w.r.t to } \\
\text { SPEEK with } 5 \mathrm{wt} \% \mathrm{~S}-\mathrm{HNT}\end{array}$} & \multirow[t]{5}{*}{ no } & \multirow[t]{5}{*}{21} \\
\hline SPEEK/5wt\% HNTs & $11 \times 10^{-3}, 25^{\circ} \mathrm{C}, 100 \% \mathrm{RH}$ & & & \\
\hline SPEEK/5wt\% S-HNTs ${ }^{\mathrm{h}}$ & $19 \times 10^{-3}, 25^{\circ} \mathrm{C}, 100 \% \mathrm{RH}$ & & & \\
\hline SPEEK & $36 \times 10^{-3}, 80^{\circ} \mathrm{C}, 100 \% \mathrm{RH}$ & \multirow{2}{*}{$\begin{array}{l}44 \% \sigma_{\mathrm{H}^{+}} \text {increase w.r.t to } \\
\text { SPEEK with } 10 \mathrm{wt} \% \text { S-HNT }\end{array}$} & & \\
\hline SPEEK/10wt \% S-HNTs ${ }^{h}$ & $52 \times 10^{-3}, 80^{\circ} \mathrm{C}, 100 \% \mathrm{RH}$ & & & \\
\hline SPEEK & $\begin{array}{l}28 \times 10^{-3}, 25^{\circ} \mathrm{C}, 100 \% \mathrm{RH} \\
4 \times 10^{-6}, 25^{\circ} \mathrm{C}, 20 \% \mathrm{RH}\end{array}$ & \multirow{2}{*}{$\begin{array}{l}54 \% \sigma_{\mathrm{H}}^{+} \text {increase w.r.t to } \\
\text { SPEEK with } 15 \mathrm{wt} \% \mathrm{~S}-\mathrm{HNT} \text { at } \\
100 \% \mathrm{RH}\end{array}$} & \multirow[t]{4}{*}{ yes } & \multirow[t]{4}{*}{19} \\
\hline SPEEK/15wt\% S-HNTs ${ }^{h}$ & $\begin{array}{l}43 \times 10^{-3}, 25^{\circ} \mathrm{C}, 100 \% \mathrm{RH} \\
1 \times 10^{-5}, 25^{\circ} \mathrm{C}, 20 \% \mathrm{RH}\end{array}$ & & & \\
\hline SPEEK & $47 \times 10^{-3}, 60^{\circ} \mathrm{C}, 100 \% \mathrm{RH}$ & \multirow{2}{*}{$\begin{array}{l}48 \% \sigma^{+}{ }^{+} \text {increase w.r.t to } \\
\text { SPEEK with } 15 \mathrm{wt} \% \text { S-HNT }\end{array}$} & & \\
\hline SPEEK/15wt \% S-HNTs ${ }^{h}$ & $70 \times 10^{-3}, 60^{\circ} \mathrm{C}, 100 \% \mathrm{RH}$ & & & \\
\hline
\end{tabular}

${ }^{a}$ MMT (Montmorillonite), ${ }^{\mathrm{b}} \mathrm{TEOS}: \mathrm{SIT}$ (silica filler, $16 \mathrm{wt} \%$ to Nafion), ${ }^{\mathrm{c}} \mathrm{MMT}-\mathrm{S}$ (-SO $\mathrm{SO}_{3} \mathrm{H}$ functionalized Montmorillonite), ${ }^{\mathrm{d}} \mathrm{Lp}$ (Laponite), ${ }^{\mathrm{e}} \mathrm{Lp}-\mathrm{g}$ (-SO $\mathrm{SO}_{3} \mathrm{H}$ functionalized Laponite), ${ }^{\mathrm{f}} \mathrm{GO}$ (graphene oxide) (6 wt $\%$ w.r.t Nafion), ${ }^{\mathrm{g}}$ sulfonated poly(ether ether ketone) (SPEEK), ${ }^{\mathrm{h}} \mathrm{S}-\mathrm{HNT}\left(-\mathrm{SO}_{3} \mathrm{H}\right.$ functionalized HNTs).

$\sigma_{\mathrm{H}}{ }^{+}$was observed at $30^{\circ} \mathrm{C}$ and $80^{\circ} \mathrm{C}$, respectively [41]. In our study, the improvements more than that reported at $100 \% \mathrm{RH}$ with the GO in Nafion are obtained at \% RH values as low as $30 \% \mathrm{RH}$ with the addition of $5 \mathrm{wt} \% \mathrm{HNT}-\mathrm{SO}_{3} \mathrm{H}$ additive (Fig. 6 and Table II). Among the carbon based materials, carbon nanotubes are not preferred due to their high electrical conductivity. Therefore, only a limited number of efficient membrane/additive examples exist including sophisticated and recent synthetic 2D conductive fillers such as MXenes in polymer matrixes [42].

Regarding the naturally occurring fibrous structures, the literature indicates that the addition of the sulfonic acid functional HNTs to other matrices such as Chitosan or SPEEK (sulfonated polyetherketones) improves the proton conductivity (Table II) [19],[21],[22], i.e. at 100\% RH, $26 \%$ and $44 \%$ of $\sigma^{+}{ }^{+}$increase at $25^{\circ} \mathrm{C}$ and $80^{\circ} \mathrm{C}$, respectively [21]. However, there are not many examples indicating the performance of the HNTs at low \% RH levels except a recent work in Ref. [19] indicating the improvements of SPEEK matrix. Yet, to the best of our knowledge, related investigation concerning Nafion matrix has not been reported.

Therefore, the Nafion/HNT-SO 3 H composites of our work are distinguished from the most of the previous work in terms of enhanced performance in $\sigma_{\mathrm{H}}{ }^{+}$which persist in the whole range of \% RH levels (at least up to $80^{\circ} \mathrm{C}$ and down to $30 \%$ RH) (Fig. $6 \mathbf{b}$ and Table II). 
To evaluate the proton conductivity improvements brought by the native $(-\mathrm{OH}),-\mathrm{NH}_{2}$ and $-\mathrm{SO}_{3} \mathrm{H}$ form of the HNTs, the ion exchange capacity (IEC) values of the composite membranes were estimated (Table III). These values provide an indication of the proton exchangeable groups present in the polymer matrix which presumably participate to the proton conduction.

The experimental IEC (IEC $\mathrm{exp}_{\text {) }}$ value for the Nafion/HNTs membrane $\left(0.91 \mathrm{meq}^{-1}\right)$ does not significantly differ than that of native Nafion (Table III). On the other hand, the incorporation of HNTs- $\mathrm{NH}_{2}$ in the Nafion matrix results in a value of $0.85 \mathrm{meq} \mathrm{g}^{-1}$. This can be explained by the weaker proton dissociation capability of the $-\mathrm{NH}_{2}$ groups under the same conditions. It is important to note that Nafion/HNTs- $\mathrm{NH}_{2}$ membrane shows an enhanced $\sigma_{\mathrm{H}}^{+}$ compared to native Nafion, in spite of a slightly lower IEC (Fig. 6) which strengthens the idea that the hydrophilic nature of the additive plays an important role in the proton transport. When the HNTs are further functionalized with $-\mathrm{SO}_{3} \mathrm{H}$ groups, the resulting composite membrane Nafion/HNTs-SO ${ }_{3} \mathrm{H}$ presents the IEC value of 0.91 meq.g ${ }^{-1}$ (Table III) which indicates that the addition of $5 \%$ of the additives does not change the IEC value of the native Nafion.

This composite has the highest $\sigma_{H}{ }^{+}$(Fig. 6 and Table III). The $\sigma_{H}{ }^{+}$value of the composite Nafion/HNT-SO 33 membrane is highly interesting since almost 2 times higher $\mathrm{\sigma H}^{+}(76 \%$ at $30^{\circ} \mathrm{C}$ and $46 \%$ at $80^{\circ} \mathrm{C}$, Table III) was achieved without significantly increasing the IEC of the membrane. Excessive dimensional swelling of the PEM should be avoided which may occur when the IEC values exceed a certain value. Beyond a certain sulfonation degree, PEMs tend to absorb too much of water or are even soluble in water, which negatively affect their mechanical resistance and water resistance [43-47]. All of these analyses suggest that nanotubes are successfully modified and their addition confers on the Nafion membrane a 
high proton mobility, probably due to the creation of a more continuous proton transport pathway without disturbing the hydrophilic/hydrophobic balance of the membrane.

Table III. Comparison of the ion exchange capacity (IEC) and proton conductivity values of Nafion and Nafion/HNTs- $\mathrm{X}\left(\mathrm{X}=-\mathrm{OH},-\mathrm{NH}_{2}\right.$ and $\left.-\mathrm{SO}_{3} \mathrm{H}\right)$ membranes.

\begin{tabular}{|c|c|c|c|c|}
\hline Membrane types & $\begin{array}{c}\text { Capacity } \\
\text { (HNTs-X) } \\
(\mathbf{w t} \%)\end{array}$ & $\begin{array}{c}\text { IEC }_{\exp } \\
\left(\text { meq g }^{-1}\right)\end{array}$ & $\begin{array}{c}\sigma_{\mathrm{H}^{+}}(\mathrm{mS} / \mathrm{cm}) \\
\left(30^{\circ} \mathrm{C} \text { et } 90 \% \mathrm{RH}\right)\end{array}$ & $\begin{array}{c}\sigma_{\mathrm{H}^{+}}(\mathrm{mS} / \mathrm{cm}) \\
\left(80^{\circ} \mathrm{C} \text { et } 90 \% \mathrm{RH}\right)\end{array}$ \\
\hline Nafion & 0 & 0.90 & 17.0 & 49.0 \\
\hline Nafion/HNTs & 5 & 0.91 & 6.3 & 59.9 \\
\hline Nafion/HNTs-NH ${ }_{2}$ & 5 & 0.85 & 36.6 & 64.0 \\
\hline Nafion/HNTs-SO${ }_{3} \mathrm{H}$ & 5 & 0.91 & 40.2 & 73.0 \\
\hline
\end{tabular}

The variation of the $\sigma_{\mathrm{H}}^{+}$as a function of temperature provides the estimation of the activation energy $\left(E_{a}\right)$ for the proton conduction and thus, the estimation of the dominant conduction mechanisms. The Ea values may also help to evaluate the improvements in the modified or newly designed membranes. Fig. 7 shows that the $\sigma_{H^{+}}{ }^{+}$of recast Nafion and Nafion/HNTs$\mathrm{SO}_{3} \mathrm{H}$ membranes measured as a function of temperature at $80 \% \mathrm{RH}$ follows the Arrhenius relationship, given in eq. (3). The $E_{a}$ determined for the recast Nafion is $0.23 \mathrm{eV}\left(22 \mathrm{~kJ} \mathrm{~mol}^{-1}\right)$ and is in good agreement with that obtained for Nafion 117 at $\mathrm{RH}=80 \%$ in reference [48]. In the presence of $\mathrm{HNTs}_{-} \mathrm{SO}_{3} \mathrm{H}$, the $\mathrm{Ea}$ value of the composite membrane is drastically decreased, i.e. $0.11 \mathrm{eV}\left(10.6 \mathrm{~kJ} \mathrm{~mol}^{-1}\right)$. Such a lower $\mathrm{E}_{\mathrm{a}}$ value suggests that the proton transport is facilitated in the presence of $-\mathrm{SO}_{3} \mathrm{H}$ modified $\mathrm{HNT}$ and this additive is also significant for proton conduction management at $80 \% \mathrm{RH}$ (it is in general reported at $\% 100$ $\mathrm{RH}$ which is a more favorable condition).

Concerning the transport mechanisms of protons in the Nafion membrane, a combination of the mechanisms, either surface diffusion, Grotthuss or vehicular/en-mass diffusion has been discussed in the literature [49-50]. Each mechanism has its own $\mathrm{E}_{\mathrm{a}}$ and depends on various factors, therefore, a variation in the nanostructure of the membrane can change the activation 
energy as well as the transport mechanism. In the present study, the $\mathrm{E}_{\mathrm{a}}$ for Nafion/HNT-SO $3 \mathrm{H}$ membranes even at $80 \% \mathrm{RH}$ stays at $0.11 \mathrm{eV}\left(10.6 \mathrm{~kJ} \mathrm{~mol}^{-1}\right)$ contrary to the higher $\mathrm{E}_{\mathrm{a}}$ of pristine Nafion determined under the same conditions $\left(0.23 \mathrm{eV}\left(22 \mathrm{~kJ} \mathrm{~mol}^{-1}\right)\right)$. This indicates that the presence of the $\mathrm{HNT}-\mathrm{SO}_{3} \mathrm{H}$ additive to Nafion alters the dominant proton conduction mechanism i.e. surface diffusion, vehicular/en-mass or Grotthuss mechanism and facilitates the proton conduction at lower $\% \mathrm{RH}$ values. This behavior can be attributed to the presence of additional hydrophilic functions, such as $\mathrm{Si}-\mathrm{OH}$ and $\mathrm{Al}-\mathrm{OH}$ groups originated from the native $\mathrm{HNTs}$ and additional $-\mathrm{NH}_{2}$ and $-\mathrm{SO}_{3} \mathrm{H}$ groups generated during the functionalization
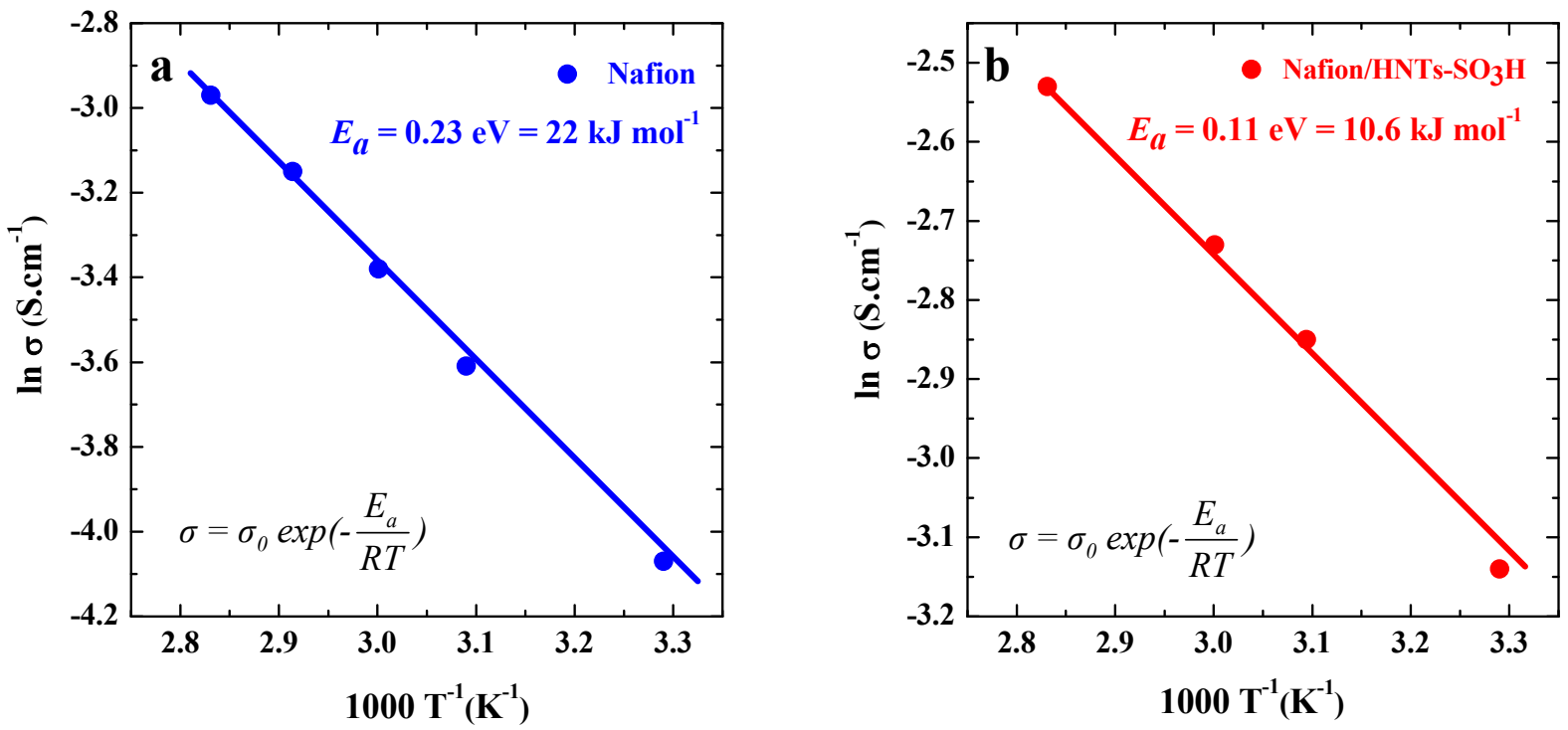

Figure 7. Arrhenius plots of proton conductivity versus membrane temperature (a) Nafion and (b) Nafion/HNTs-SO ${ }_{3} \mathrm{H}$. The activation energies for proton conduction at $80 \% \mathrm{RH}$ are calculated from the Eq. 3 ( $\mathrm{R}$ equals to $8.314 \mathrm{~J} \mathrm{~K}^{-1} \mathrm{~mol}^{-1}$ representing the universal gas constant, $\sigma$ is the proton conductivity, $\sigma_{0}$ is the pre-exponential factor, $\mathrm{T}$ is the temperature $(\mathrm{K})$ and $\mathrm{E}_{\mathrm{a}}$ is activation energy) and given on the graph.

steps which have a higher propensity to retain water and then, to limit the dependence of the $\sigma_{H^{+}}$on hydration. 
An unambiguous determination of the dominant conduction mechanism is rather challenging, but a lower activation energy in the composite membrane indicates that slower mechanistic pathway i.e. surface conduction mechanism can be eliminated. It is noted that the Ea value for the Nafion/HNT-SO 3 H is in the lower limit of the $\mathrm{E}_{\mathrm{a}}$ range corresponding to the Grotthuss type mechanism (between $\sim 0.1$ and $\sim 0.4 \mathrm{eV}$ ) [19][51]. This can be interpreted by the coexistence of the two transport mechanisms, Grotthuss (hoping) and vehicular/en-mass diffusion which probably jointly govern the proton conduction in the composite membrane but their individual contribution to overall mechanism differs compared to pristine Nafion. The co-existence of vehicle-type and Grotthuss-type proton transport has also been discussed for other composite membranes such as ionic liquid templated porous SPEEK nanofiber mat filled with chitosan [52], functionalized graphene oxide and its composites with SPEEK and chitosan $[53,54]$.

The present composite membranes with a lower value of $E_{a}$ than that of pristine Nafion present significant improvements in the $\sigma_{\mathrm{H}}{ }^{+}$. This behavior can be attributed to the presence of additional hydrophilic functions, such as $\mathrm{Si}-\mathrm{OH}$ and $\mathrm{Al}-\mathrm{OH}$ groups originated from the native HNTs and additional $-\mathrm{NH}_{2}$ and $-\mathrm{SO}_{3} \mathrm{H}$ groups generated during the functionalization steps which have a higher propensity to retain water and then, limit the dependence of the $\sigma_{\mathrm{H}}{ }^{+}$on hydration. The improvements observed in the water-uptake behavior of the membranes in the presence of $\mathrm{HNT}-\mathrm{SO}_{3} \mathrm{H}$ (measured by using quartz crystal microbalance, data not shown) support this interpretation, i.e., the water uptake following a \% RH change from 30 to $90 \% \mathrm{RH}$ was increased almost 3 times in the presence of $\mathrm{HNT}-\mathrm{SO}_{3} \mathrm{H}$.

\section{Conclusions}

Naturally occurring HNTs were structurally modified by a condensation reaction between the surface hydroxyls of HNTs and the ethoxysilane groups of the APTES resulting in the $-\mathrm{NH}_{2}$ 
grafted HNTs. Subsequently, nanotubes containing $-\mathrm{SO}_{3} \mathrm{H}$ functional groups has been prepared by a ring opening of propane sultone induced by nucleophilic addition of the amino groups generated in the previous step. These functionalization stages confer desirable physical attributes on HNTs and render them suitable as membrane additives which contribute to the $\sigma_{\mathrm{H}}{ }^{+}$and the hydrophilic/hydrophobic balance of the resulting composite membrane. Among the three different types of HNTs additives (HNTs, HNTs- $\left.\mathrm{NH}_{2}, \mathrm{HNTs}^{-} \mathrm{SO}_{3} \mathrm{H}\right)$ the $\mathrm{SO}_{3} \mathrm{H}$ functionalized form resulted in the highest $\sigma_{\mathrm{H}}{ }^{+}$although certain improvements were observed with the native and $-\mathrm{NH}_{2}$ functionalized form. The Nafion/HNT-SO $3 \mathrm{H}$ composites of our work are distinguished from the most of the previous work in terms of enhanced performance in $\sigma_{\mathrm{H}}^{+}$which persist in the whole range of \% RH levels (at least up to $80^{\circ} \mathrm{C}$ and down to $30 \% \mathrm{RH})$. It is noted that the $\sigma_{\mathrm{H}}^{+}$values are almost 2 times higher than native Nafion in the low humidity region $(30 \%-50 \%)$ and $80{ }^{\circ} \mathrm{C}$.

Concerning the transport mechanisms of protons, in the presence of $\mathrm{HNTs}_{\mathrm{s}} \mathrm{SO} \mathrm{H}_{3} \mathrm{H}$, the $\mathrm{E}_{\mathrm{a}}$ value of the composite membrane is drastically decreased, i.e. $0.11 \mathrm{eV}\left(10.6 \mathrm{~kJ} \mathrm{~mol}^{-1}\right)$. Such a lower $\mathrm{E}_{\mathrm{a}}$ value suggests that the proton transport is facilitated in the presence of $-\mathrm{SO}_{3} \mathrm{H}$ modified HNT. Overall improvements of the $\sigma_{\mathrm{H}}^{+}$in the presence of the HNTs based additives are attributed to (i) the presence of additional hydrophilic functions, such as $\mathrm{Si}-\mathrm{OH}$ and $\mathrm{Al}-\mathrm{OH}$ groups originated from the native $\mathrm{HNTs}$ and additional $-\mathrm{NH}_{2}$ and $-\mathrm{SO}_{3} \mathrm{H}$ groups generated during the functionalization steps which have a high propensity to retain water and (ii) a reinforced proton conducting network with additional $-\mathrm{SO}_{3} \mathrm{H}$ groups which may assure a continuous pathway and result in low values of resistance for proton conduction. Our results suggest that the Nafion/HNT- $\mathrm{SO}_{3} \mathrm{H}$ composites are promising as PEMs, and potentially applicable in electrodialysis, water electrolyzes and as well as in batteries as separators. 


\section{Supporting Information Available}

XRD patterns and FEG-SEM images of the HNTs, HNTs-NH 2 and $\mathrm{HNTs}_{2} \mathrm{SO}_{3} \mathrm{H}$ powders.

\section{Acknowledgements}

I.R. acknowledges "The Emmag Programme" for the financial support of her Ph.D. thesis. The authors thank Ms. Françoise Pillier and Ms. Sandra Cassal for the FEG-SEM and HRTEM measurements, respectively.

\section{References}

[1] K. A. Mauritz and R. B. Moore, "State of understanding of Nafion," Chem. Rev., vol. 104, no. 10, pp. 4535-4586, 2004.

[2] Y. M. Kim, S. H. Choi, H. C. Lee, M. Z. Hong, K. Kim, and H.-I. Lee, "Organicinorganic composite membranes as addition of $\mathrm{SiO}_{2}$ for high temperature-operation in polymer electrolyte membrane fuel cells (PEMFCs)," Electrochim. Acta, vol. 49, no. 26, pp. 4787-4796, 2004.

[3] M.-K. Song, S.-B. Park, Y.-T. Kim, K.-H. Kim, S.-K. Min, and H.-W. Rhee, "Characterization of polymer-layered silicate nanocomposite membranes for direct methanol fuel cells," Electrochim. Acta, vol. 50, no. 2, pp. 639-643, 2004.

[4] R. Gosalawit, S. Chirachanchai, S. Shishatskiy, and S. P. Nunes, "KrytoxMontmorillonite-Nafion ${ }^{\circledR}$ nanocomposite membrane for effective methanol crossover reduction in DMFCs," Solid State Ionics, vol. 178, no. 29, pp. 1627-1635, 2007.

[5] R. H. Alonso, L. Estevez, H. Lian, A. Kelarakis, and E. P. Giannelis, "Nafion-clay nanocomposite membranes: morphology and properties," Polymer (Guildf)., vol. 50, no. 11, pp. 2402-2410, 2009.

[6] Y.-F. Lin, C.-Y. Yen, C.-H. Hung, Y.-H. Hsiao, and C.-C. M. Ma, “A novel composite 
membranes based on sulfonated montmorillonite modified Nafion ${ }^{\circledR}$ for DMFCs," $J$. Power Sources, vol. 168, no. 1, pp. 162-166, 2007.

[7] M. Paidar, V. Fateev and K. Bouzek, "Membrane electrolysis-History, current status and perspective," Electrochim. Acta, vol. 209, pp. 737-756, 2016.

[8] N. White, M. Misovich, A. Yaroshchuk, M. L. Bruening, "Coating of Nafion membranes with polyelectolyte multilayers to achieve high monovalent/divalent cation electrodialysis selectivities" ACS Appl. Mater. Interfaces, vol.5, pp. 6620-6628, 2015.

[9] P. N. Pintauro, "Perspectives on membranes and separators for electrochemical energy conversion and storage devices," Polym. Rev., vol. 55, no. 2, pp. 201-207, 2015.

[10] A. Goni-Urtiaga, D. Presvytes, K. Scott, "Solid acids as electrolyte materials for proton exchange membrane (PEM) electrolysis: Review" Int. J. Hydrog. Energy, vol. 37, pp. 3358-3372, 2012.

[11] W. Dai, H. Wanga, X-Z Yuan, J. J. Martin, D. Yang, J. Qiao, J. Ma, “A review on water balance in the membrane electrode assembly of proton exchange membrane fuel cells" Int. J. Hydrog. Energy, 34, (2009), 9461-9478.

[12] K. Ketpang, S. Shanmugam, C. Suwanboon, N. Chanunpanich, D. Lee, "Efficient water management of composite membranes operated in Polymer electrolyte membrane fuel cells under low relative humidity" J. Membr. Sci., vol. 493, pp. 285$298,2015$.

[13] H.S. Thiam, W.R.W. Daud, S.K. Kamarudin, A.B. Mohammad, A.A.H. Kadhum, K.S. Loh, E.H. Majlan, “Overview on nanostructured membrane in fuel cell Applications" Int. J. Hydrog. Energy, vol. 36, pp. 3187-3205, 2011.

[14] H. Wang, X. Li, X. Zhuang, B. Cheng, W. Wang, W. Kang, L. Shi, H. Li, "Modification of Nafion membrane with biofunctional $\mathrm{SiO}_{2}$ nanofiber for proton exchange membrane fuel cells” J. Power Sources, vol. 340, pp. 201-209, 2017. 
[15] C. Beauger, G. Lainé, A. Burr, A. Taguet, B. Otazaghine, and A. Rigacci, "Nafion®_sepiolite composite membranes for improved proton exchange membrane fuel cell performance," J. Memb. Sci., vol. 430, pp. 167-179, 2013.

[16] A. Kelarakis, R. Herrera Alonso, L. Huiqin, E. Burgaz, L. Estevez, and E. P. Giannelis, "Nanohybrid nafion membranes for fuel cells," in ACS symposium series, 2010, vol. 1034, pp. 171-185.

[17] R. Kannan, B. A. Kakade, and V. K. Pillai, "Polymer Electrolyte Fuel Cells Using Nafion Based Composite Membranes with Functionalized Carbon Nanotubes," Angew. Chemie Int. Ed., vol. 47, no. 14, pp. 2653-2656, 2008.

[18] F. Xu, S. Mu, and M. Pan, "Mineral nanofibre reinforced composite polymer electrolyte membranes with enhanced water retention capability in PEM fuel cells," $J$. Memb. Sci., vol. 377, no. 1, pp. 134-140, 2011.

[19] X. Liu, S. He, G. Song, H. Jia, Z. Shi, S. Liu, L. Zhang, J. Lin, and S. Nazarenko, "Proton conductivity improvement of sulfonated poly (ether ether ketone) nanocomposite membranes with sulfonated halloysite nanotubes prepared via dopamine-initiated atom transfer radical polymerization," J. Memb. Sci., vol. 504, pp. 206-219, 2016.

[20] H. Zhang, T. Zhang, J. Wang, F. Pei, Y. He, and J. Liu, "Enhanced Proton Conductivity of Sulfonated Poly (ether ether ketone) Membrane Embedded by Dopamine Modified Nanotubes for Proton Exchange Membrane Fuel Cell," Fuel Cells, vol. 13, no. 6, pp. 1155-1165, 2013.

[21] H. Zhang, C. Ma, J. Wang, X. Wang, H. Bai, and J. Liu, "Enhancement of proton conductivity of polymer electrolyte membrane enabled by sulfonated nanotubes," Int. J. Hydrogen Energy, vol. 39, no. 2, pp. 974-986, 2014.

[22] H. Bai, H. Zhang, Y. He, J. Liu, B. Zhang, and J. Wang, "Enhanced proton conduction 
of chitosan membrane enabled by halloysite nanotubes bearing sulfonate polyelectrolyte brushes," J. Memb. Sci., vol. 454, pp. 220-232, 2014.

[23] P. Yuan, P. D. Southon, Z. Liu, M. E. R. Green, J. M. Hook, S. J. Antill, and C. J. Kepert, "Functionalization of halloysite clay nanotubes by grafting with $\gamma$ aminopropyltriethoxysilane," J. Phys. Chem. C, vol. 112, no. 40, pp. 15742-15751, 2008.

[24] I. Ressam, N. Krins, C. Laberty Robert, M. Selmane, M. Lahcini, M. Raihane, A. El Kadib, H. Perrot, and O. Sel, "Sulfonic Acid Functionalized Chitosan as a Sustainable Component for Proton Conductivity Management in PEMs," ChemistrySelect, vol. 2, no. 8 , pp. 2503-2511, 2017.

[25] S. Barrientos-Ramírez, G. M. de Oca-Ramírez, E. V Ramos-Fernández, A. SepúlvedaEscribano, M. M. Pastor-Blas, and A. González-Montiel, "Surface modification of natural halloysite clay nanotubes with aminosilanes. Application as catalyst supports in the atom transfer radical polymerization of methyl methacrylate," Appl. Catal. A Gen., vol. 406, no. 1, pp. 22-33, 2011.

[26] S. El Hankari, A. El Kadib, A. Finiels, A. Bouhaouss, J. J. E. Moreau, C. M. Crudden, D. Brunel, and P. Hesemann, "SBA 15 Type Organosilica with 4 Mercapto N, $\mathrm{N}$ bis (3 $\mathrm{Si}$ propyl) butanamide for Palladium Scavenging and Cross Coupling Catalysis,” Chem. Eur. J., vol. 17, no. 32, pp. 8984-8994, 2011.

[27] D. Britt, C. Lee, F. J. Uribe-Romo, H. Furukawa, and Omar M. Yaghi "Ring-Opening Reactions within Porous Metal-Organic Frameworks” Inorg. Chem. Vol 49, pp. 6387$6389,2010$.

[28] E. Abdullayev, A. Joshi, W. Wei, Y. Zhao, and Y. Lvov, "Enlargement of halloysite clay nanotube lumen by selective etching of aluminum oxide," ACS Nano, vol. 6, no. 8, pp. 7216-7226, 2012. 
[29] P. Sun, G. Liu, D. Lv, X. Dong, J. Wu, and D. Wang, "Effective activation of halloysite nanotubes by piranha solution for amine modification via silane coupling chemistry," RSC Adv., vol. 5, no. 65, pp. 52916-52925, 2015.

[30] T. Kim, S. Kim, D K Lee, B Seo and C-S Lim, "Surface treatment of halloysite nanotubes with sol-gel reaction for the preparation of epoxy composites" $R S C A d v$., vol 7, pp. 47636-47642, 2017.

[31] A. Riza Erdogan, I. Kaygusuz, and C. Kaynak, "Influences of aminosilanization of halloysite nanotubes on the mechanical properties of polyamide 6 nanocomposites," Polym. Compos., vol. 35, no. 7, pp. 1350-1361, 2014.

[32] S. A. Hashemifard, A. F. Ismail, and T. Matsuura, "Mixed matrix membrane incorporated with large pore size halloysite nanotubes (HNT) as filler for gas separation: experimental,” J. Colloid Interface Sci., vol. 359, no. 2, pp. 359-370, 2011.

[33] M. Maréchal, C. Laberty-Robert, and S. Livi, in Nanomaterials for Sustainable Energy ACS Symposium Series, Vol. 1213, Chapter 5, "Hybrid Electrolytes,” 2015, p.73.

[34] C. H. Rhee, H. K. Kim, H. Chang, and J. S. Lee, "Nafion/sulfonated montmorillonite composite: a new concept electrolyte membrane for direct methanol fuel cells," Chem. Mater., vol. 17, no. 7, pp. 1691-1697, 2005.

[35] N. N. Krishnan, D. Henkensmeier, J. H. Jang, H-J. Kim, "Nanocomposite Membranes for Polymer Electrolyte Fuel Cells," Macromol. Mater. Eng., vol. 299, pp. 1031-1041, 2014.

[36] N. Ramaswamy, T. M. Arruda, W. Wen, N. Hakim, M. Saha, A. Gullá, and S. Mukerjee, "Enhanced activity and interfacial durability study of ultra low Pt based electrocatalysts prepared by ion beam assisted deposition (IBAD) method," Electrochim. Acta, vol. 54, no. 26, pp. 6756-6766, 2009.

[37] S. Goswami, S. Klaus, and J. Benziger, "Wetting and absorption of water drops on 
Nafion films," Langmuir, vol. 24, no. 16, pp. 8627-8633, 2008.

[38] H. M. Yu, C. Ziegler, M. Oszcipok, M. Zobel, and C. Hebling, "Hydrophilicity and hydrophobicity study of catalyst layers in proton exchange membrane fuel cells," Electrochim. Acta, vol. 51, no. 7, pp. 1199-1207, 2006.

[39] C. Felice, S. Ye, and D. Qu, "Nafion- montmorillonite nanocomposite membrane for the effective reduction of fuel crossover," Ind. Eng. Chem. Res., vol. 49, no. 4, pp. $1514-1519,2010$.

[40] P. Bébin, M. Caravanier, and H. Galiano, "Nafion®/clay-SO $3{ }_{3} \mathrm{H}$ membrane for proton exchange membrane fuel cell application,” J. Memb. Sci., vol. 278, no. 1, pp. 35-42, 2006.

[41] R. Kumar, C. Xu, and K. Scott, "Graphite oxide/Nafion composite membranes for polymer electrolyte fuel cells," RSC $A d v$., vol. 2, no. 23, pp. 8777-8782, 2012.

[42] Y. Liu, J. Zhang, X. Zhang, Y. Li, and J. Wang, "Ti3C2T x Filler Effect on the Proton Conduction Property of Polymer Electrolyte Membrane," ACS Appl. Mater. Interfaces, vol. 8, no. 31, pp. 20352-20363, 2016.

[43] O. Sel, A. Soules, B. Ameduri, B. Boutevin, C. Laberty Robert, G. Gebel, and C. Sanchez, "Original Fuel Cell Membranes from Crosslinked Terpolymers via a 'Solgel' Strategy," Adv. Funct. Mater., vol. 20, no. 7, pp. 1090-1098, 2010.

[44] T. Higashihara, K. Matsumoto, and M. Ueda, "Sulfonated aromatic hydrocarbon polymers as proton exchange membranes for fuel cells," Polymer (Guildf)., vol. 50, no. 23, pp. 5341-5357, 2009.

[45] R. Y. M. Huang, P. Shao, C. M. Burns, and X. Feng, "Sulfonation of poly (ether ether ketone)(PEEK): kinetic study and characterization,” J. Appl. Polym. Sci., vol. 82, no. 11, pp. 2651-2660, 2001.

[46] B. Yang and A. Manthiram, "Sulfonated poly (ether ether ketone) membranes for direct 
methanol fuel cells," Electrochem. solid-state Lett., vol. 6, no. 11, pp. A229-A231, 2003.

[47] A. D. Liyanage, J. P. Ferraris, I. H. Musselman, D.-J. Yang, T. E. Andersson, D. Y. Son, and K. J. Balkus, "Nafion-sulfonated dendrimer composite membranes for fuel cell applications," J. Memb. Sci., vol. 392, pp. 175-180, 2012.

[48] G. Blumenthal, M. Cappadonia, and M. Lehmann, "Investigation of the proton transport in nafion ${ }^{\circledR}$ membranes as a function of direction, temperature and relative humidity," Ionics (Kiel)., vol. 2, no. 2, pp. 102-106, 1996.

[49] P. Knauth and J. Schoonman, Nanocomposites: ionic conducting materials and structural spectroscopies. Springer Science \& Business Media, 2007.

[50] S. J. Paddison and R. Paul, "The nature of proton transport in fully hydrated Nafion ${ }^{\circledR}, "$ Phys. Chem. Chem. Phys., vol. 4, no. 7, pp. 1158-1163, 2002.

[51] Y. G. Jin, S. Z. Qiao, J. C. D. da Costa, B. J. Wood, B. P. Ladewig, and G. Q. Lu, "Hydrolytically stable phosphorylated hybrid silicas for proton conduction," $A d v$. Funct. Mater., vol. 17, no. 16, pp. 3304-3311, 2007.

[52] C. Hou, X. Zhang, Y. Li, G. Zhou and J. Wang, "Porous nanofibrous composite membrane for unparalleled proton conduction,” J. Memb. Sci., vol. 550, pp. 136-144, 2018.

[53] L. Zhao, Y. Li, H. Zhang, W. W., J. Liu, and J. Wang, "Constructing protonconductive highways within an ionomer membrane by embedding sulfonated polymer brush modified graphene oxide,” J. Power Sources, vol. 286, pp. 445-457, 2015.

[54] J. Wang, H. Bai, J. Zhang, L. Zhao, P. Cheng, Y. Li and J. Liu, "Acid-base block copolymer brushes grafted graphene oxide to enhance proton conduction of polymer electrolyte membrane,” J. Memb. Sci., vol. 531, pp. 47-58, 2018. 